\title{
Lifetime Generational Accounts for the Netherlands
}

Harry ter Rele and Claudio Labanca 



\section{CPB Discussion Paper}

No 170

Lifetime Generational Accounts for the Netherlands

Harry ter Rele and Claudio Labanca 
CPB Netherlands Bureau for Economic Policy Analysis

Van Stolkweg 14

P.O. Box 80510

2508 GM The Hague, the Netherlands

Telephone $\quad+31703383380$

Telefax $\quad+31703383350$

Internet www.cpb.nl 


\section{CPB Discussion Paper}

No 170

Lifetime Generational Accounts for the Netherlands

Harry ter Rele and Claudio Labanca 
CPB Netherlands Bureau for Economic Policy Analysis

Van Stolkweg 14

P.O. Box 80510

2508 GM The Hague, the Netherlands

Telephone $\quad+31703383380$

Telefax + +31703383350

Internet www.cpb.nl 


\section{Abstract in English}

Conventional Generational Accounting only includes future benefits and burdens from the government. This paper's contribution is to include past benefits and burdens as well, and in this way to provide a full lifetime account of how much current and future generations benefit from government, in net terms, under various future policy lines. The calculations are carried out for the Netherlands and for the cohorts born as from 1946. The more complete picture may be helpful for political decision making on equitable intergenerational policies. A second contribution of this paper is that it uses a more comprehensive benefit concept than other such studies by including non-cash benefits as well.

The results point out that the lifetime net benefits are positive for almost all of the cohorts considered. Only the very first of the post war cohorts have negative net benefits. Net benefits rise sharply for the younger cohorts, mainly due to increasing benefits from education, health care and general government. They reach a peak for those born between 1960 and 1990. Due to austerity measures that are necessary to restore sustainability of public finances, they decline again for the cohorts after 1990.

Key words: public finances, generational accounting

JEL code: $H 23$

\section{Abstract in Dutch}

Conventionele generatierekeningen betrekken alleen toekomstige baten en lasten van de overheid in de berekening. De bijdrage van dit paper is om ook het verleden in de berekeningen te betrekken en op deze manier een beeld te geven van de netto profijten over het hele leven, onder verschillende beleidsopties, van zowel de huidige als de toekomstige generaties. De berekeningen hebben betrekking op de cohorten die zijn geboren vanaf 1946. Het meer complete beeld kan behulpzaam zijn als de beleidsopties verschillend uitwerken over generaties. Een tweede bijdrage van dit paper is dat het een meer omvattend profijtbegrip hanteert dan andere studies doordat het ook de niet-monetaire baten meeneemt.

De resultaten geven aan dat het netto levensprofijt positief is voor bijna alle betrokken cohorten. Alleen de allereerste naoorlogse cohorten hebben een negatief netto profijt. De netto profijten stijgen sterk voor de jongere cohorten, vooral als gevolg van hogere baten van onderwijs, zorg en openbaar bestuur. De cohorten die zijn geboren tussen 1960 en 1990 profiteren het meest. Jongere cohorten hebben weer minder profijt als gevolg van de bezuinigingsmaatregelen die nodig zijn om de overheidsfinanciën houdbaar te maken.

Steekwoorden: overheidsfinanciën, generatierekeningen 


\section{Contents}

1 Introduction and summary $\quad 5$

2 Methodology $\quad 8$

2.1 Lifetime Generational Accounting $\quad 8$

2.2 Differences with conventional Generational Accounting 11

3 Data and assumptions $\quad 13$

$\begin{array}{lll}3.1 & \text { An insight into past government finances } & 13\end{array}$

$\begin{array}{lll}3.2 & \text { Current age profiles } & 16\end{array}$

$\begin{array}{lll}3.3 & \text { Past and future age profiles } & 19\end{array}$

$4 \quad$ Baseline results $\quad 22$

4.1 The Lifetime Generational Accounts (LGAs) 22

4.2 The origins of the positive net benefits 25

$\begin{array}{lll}5 & \text { A decomposition } & 26\end{array}$

$\begin{array}{lll}6 & \text { Sensitivity analysis } & 30\end{array}$

$\begin{array}{lll}6.1 & \text { Age profile related sensitivity analysis } & 30\end{array}$

6.2 Sensitivity analysis related to the discount rate 32

$7 \quad$ Other Lifetime Generational Accounting studies $\quad 34$

$8 \quad$ Reflection on policy implications $\quad 37$

$\begin{array}{lr}\text { References } & 39\end{array}$ 


\section{Introduction and summary}

This paper constructs lifetime generational accounts for the Netherlands. ${ }^{1}$ Its purpose is to measure the net effect of benefits from expenditure and taxation on current and future generations, and the differences therein between generations. One of its contributions is that it extends the conventional way generational accounts, as introduced by Auerbach et al. (1991), are set up. Apart from including only future taxes and benefits from government in the accounts, as conventional generational accounting (GA) does, it includes past taxes and benefits as well. The purpose of this extension is to produce lifetime generational accounts for the currently living generations. In conventional GA, this is only possible for the very youngest of the current generations and for the yet unborn generations. Having full lifetime accounts obviously enhances the comparability of the outcomes of current and future generations, and may therefore be more helpful for political decision making on equitable generational policies. This is especially so because there is a strong age dependency in the net benefit from government during the course of life. Therefore, constructing lifetime generational accounts (LGAs) not only leads to a more complete picture, it also increases the comparability of the outcomes due to the fact that they don't anymore cover different spans of the life cycle.

This paper also provides a methodological contribution. It extends the current literature on LGA by using a more comprehensive measure of net benefits from government. It does not restrict its net benefit concept to taxes and cash transfers from government but includes noncash benefits as well, such as from education and health care. As this paper will show, these turn out to be important drivers of the overall results for the Netherlands. Compared to the other studies, this paper also provides a more detailed decomposition of the differences in outcome between generations.

There are only a few LGA studies in the world. This may be due to a lack of data. The construction of accounts of past benefits and burdens from government requires the availability of detailed data on both the size and composition of past government expenditure and taxes. A second reason may be that the processing of these past data, if available, may be very time consuming.

This study nonetheless embarks on the construction of such LGAs. We use the CPB historical data set on Dutch government accounts. The data go back far enough to enable the construction of generational accounts of the cohorts born in 1946 and later. This requires however the use of a number of assumptions, most specifically regarding the age specificity of past expenditure and tax items. We test the sensitivity of the outcomes for these assumptions. The outcomes turn out be relatively robust to changes in the assumptions.

\footnotetext{
${ }^{1}$ We would like to thank Frits Bos, Albert van der Horst, Bas Jacobs and Bas ter Weel for their useful comments on an earlier version of this paper and André Nibbelink for his excellent computational assistance.
} 
Figure 1.1 shows the baseline results in four sustainable scenarios. These are discussed in detail in section 4 and represent a wide range of reasonable possibilities of achieving sustainable policy. It shows that in all these scenarios, measured over the full life cycle, almost all cohorts born since 1946 benefit from the government. This is made possible by the government revenues from natural resources (gas) and the net contributions to public finances of the cohorts born before 1946, implying negative net benefits for these cohorts. Also the very first of the post-war cohorts in our measurements show negative net benefits. However, net benefits rise sharply for the cohorts born after 1946, become positive as from the cohort born in 1948, and reach a peak for the cohorts born between 1960 and 1990. Depending on how policies are adjusted in the future to achieve sustainable public finances, this peak amounts to 8 to $9 \%$ of lifetime income. The strong rise between the cohorts born in 1946 and 1960 results mainly from the strong post war increase in government spending on education, health care and general government. The cohorts born after 1960 have thus benefited substantially more from these government provisions than the first post war cohorts.

Net benefits decline for the cohorts born after 1990. This is due to the fact that the current system of public finances is unsustainable and large adjustments are necessary, leading to cuts in expenditure and/or higher taxes. The younger the cohort, the more they are affected. Our measurements nonetheless show that net benefits will remain positive, at $1 \frac{1}{2}$ to $2 \frac{1}{2} \%$ of lifetime income, for even the very youngest of the currently living cohorts as well as for future cohorts.

This outcome turns out to be relatively robust to the various ways in which the system of public arrangements can reasonably be adjusted in order to achieve sustainable public finances.

\section{Figure 1.1 Lifetime Generational Accounts in four sustainable scenarios (as a percentage of lifetime income)}

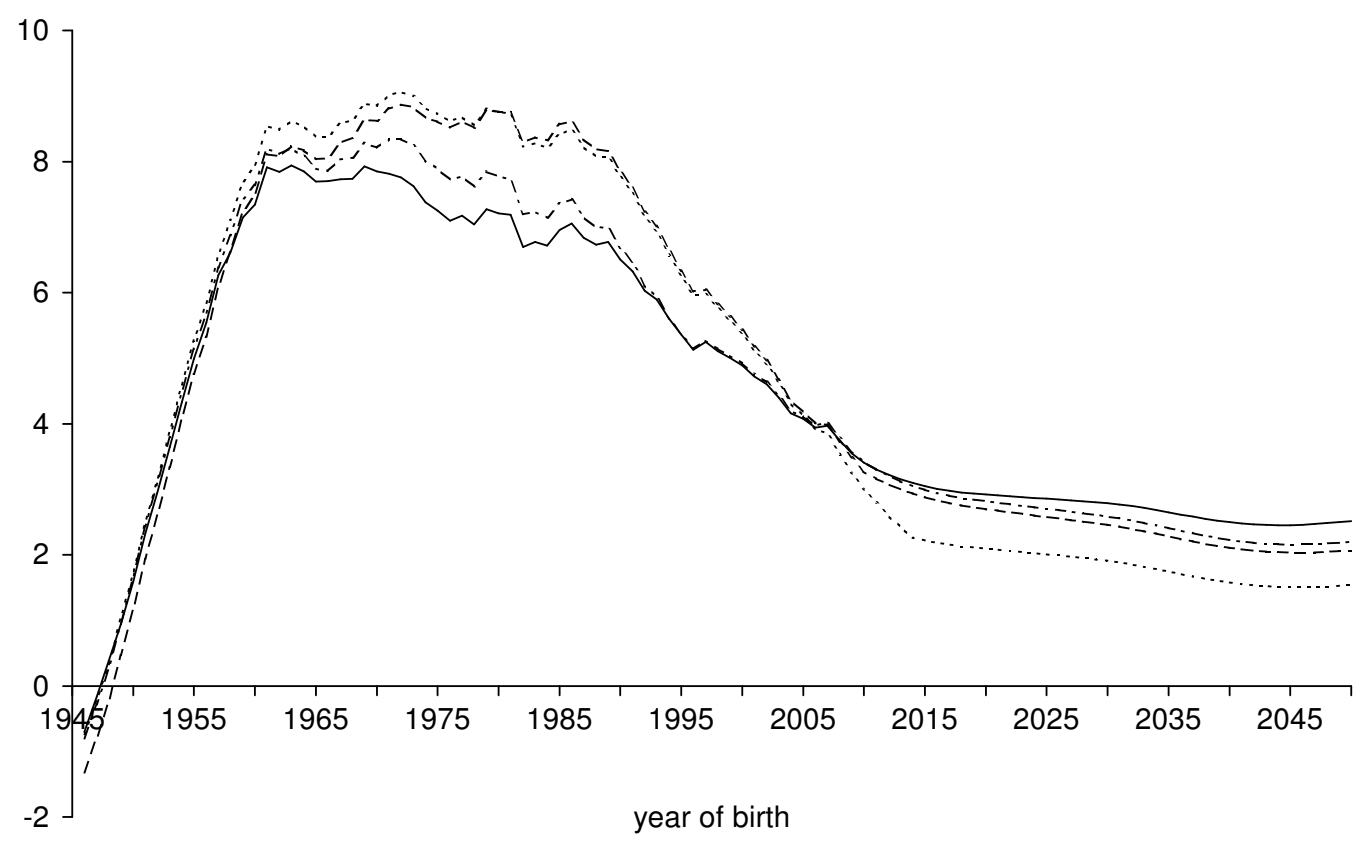


This paper measures the net benefits that result from actual taxes paid to and benefits received from the government. It does not take account of the welfare effects of behavioural responses that result from changes in taxation and the welfare system. It also does not capture other ways in which the government influences the welfare of cohorts such as through regulation and measures affecting asset values in the private sector. Especially in the housing sector this involves substantial intergenerational transfers as restrictive government spatial policies have limited the supply of land allocated to housing. This factor has widely been considered ${ }^{2}$ to have contributed much to the sharp, around $100 \%$ in real terms, rise in house prises in the 1990's which benefited the house owning cohorts of the time, mostly those born before 1965, and was disadvantageous to the younger cohorts that entered the housing market in later years. This involves considerable intergenerational transfers which have certainly been, in part, an offsetting factor to the intergenerational effects presented in this paper.

This paper also excludes transfers between generations in other sectors of the economy such as in the second pillar pension system, transfers in the private sector through inheritances, and possibly the effects of a deteriorated natural environment. The second pillar pension system in particular may provide a large net benefit to the cohorts born before 1950 as these benefit from favourable early retirement schemes which are abolished for younger cohorts. However, this is not yet investigated in detail. This subject is put on the CPB agenda for the coming years. Including the effects of the second pillar is particularly desirable because participating in this form of saving is mandatory. Therefore, these transfers might be considered to be the result of collective arrangements.

The rest of the paper is organised as follows. The next section discusses the methodology applied in this paper and briefly discusses the difference with conventional GA. Section 3 discusses the data and assumptions and section 4 discusses the base case results. Section 5 provides a decomposition of the results into budgetary items, thereby pointing out the main drivers of the differences in outcome between generations. Section 6 performs a sensitivity analysis, section 7 discusses other LGA studies in the world and section 8 reflects on the importance of the LGAs for future policy. A technical appendix, providing a detailed description of the methodology, is published separately.

\footnotetext{
${ }^{2}$ See CPB (1999) and Besseling et al. (2008).
} 


\section{$2 \quad$ Methodology}

This section presents the methodology. It discusses the net benefit concept that is used in the calculations and the expressions with which the LGAs are constructed. This is followed by a brief summary of the advantages and disadvantages of generational accounting and a brief discussion on how the CPB methodology differs from that of the inventors of GA.

\subsection{Lifetime Generational Accounting}

\subsubsection{The Net Benefit Concept used in this paper}

GA measures how much future and current generations benefit from government in net terms, and the differences therein between generations. The first necessary step is to define the concept of the net benefit from government. The definition that is used in this paper is the one outlined in Ter Rele (1998) in developing a GA model for the Netherlands:

$$
N B=C+I B C+T R-T-S
$$

In (2.1) C stands for government consumption. Benefits from it are assumed to equal expenditure. This term captures direct government expenditure and it is composed of several expenditure items. More precisely it includes expenditure on general government (apart from investments in buildings), defense, subsidies, transfers abroad, education (apart from investments in school buildings) and health care. ${ }^{3}$ However, it excludes government investments. The benefits from investments are captured by IBC, which represents the imputed benefits from the government stock of physical capital. TR stands for transfer payments. These three terms represent the benefits from government. The burden imposed by government is captured by $\mathrm{T}$, i.e. taxes and social security contributions, the corporation tax, indirect taxes, and by seigniorage $(\mathrm{S})$.

Government revenues and expenses are included into the net benefits concept only if there is no exchange in return. This means that interest payments are not considered as benefits from government because these are the returns on an investment and reflect market conditions. Accordingly, capital income from financial assets is not considered as a burden. Government profits from natural resources (gas extraction) are also not included as a burden as these profits are the result of a government delivery of goods. These profits do however increase the amount of net benefits the government can distribute in the future. They increase the overall net benefit the government can provide and can thus be considered to be a windfall gain.

\footnotetext{
${ }^{3}$ Moreover, non-tax revenues (apart from revenues from natural resources and from capital income) are subtracted because this item, that largely consists of government sales, can be seen as a counteritem of direct government expenditure and serves as a correction for the benefits from expenditure. 
The imputed benefits (IBC) derived from the government stock of physical assets, such as from infrastructure, are calculated as

$$
I B C=D E+r \cdot A P H,
$$

where $D E$ stands for depreciation, $r$ for the real discount rate and $A P H$ for the stock of public physical capital. There is no observable measure for these benefits and the first GA models, like in Auerbach et al. (1991), ignored this form of benefit. Ter Rele (1998) introduced the use of an imputed benefit term. It appreciates the fact that investments generate future benefits, rather than current benefits, and that current benefits from investments result from the accumulation of past investments.

Finally seigniorage ( $S$ ) is the opportunity cost paid by all those who hold banknotes and coins. The latter, in fact, do not provide holders with any interest payment thus implying a loss of return.

\section{The expressions for the LGAs}

In section 4, we will present the outcomes of the LGAs as lifetime net benefits as a percentage of lifetime incomes. This corresponds with how Gokhale et al. (1997) and Auerbach et al. (1994) present LGAs and may be the best way to provide an intuitive notion about the importance of the outcomes. The expression for these outcomes are:

$$
L G A_{k}=\frac{\sum_{s=k}^{k+T} N B_{s, k} A_{s, k} \frac{1}{(1+r)^{s-k}}}{\sum_{s=k}^{k+T} L I_{s, k} \frac{1}{(1+r)^{s-k}}}
$$

where $L G A_{k}$ stands for lifetime net benefits of the cohort born in $k$ as a percentage of its lifetime (pre-tax) primary income, $N B_{s, k}$ for the average net benefit of an individual born in year $k$ in year $s, A_{s, k}$ the number of individuals born in $k$ that are resident in the Netherlands in year s, and $L I_{s, k}$ for primary income of cohort $k$ in year $s$.

Primary income here includes labour income, income of the self-employed and government revenues from indirect taxation. The latter is necessary in order to obtain a pure measure of pretax income because indirect taxes form a wedge between the primary incomes earned in the economy and the primary incomes accruing to households in the form of labour income, income of the self-employed and capital income as measured in the National Accounts. Indirect taxes thus reduce the primary incomes received by households. Not including indirect taxes in the income measure would ignore this, and overestimate the tax share in income as well as the benefit share. 
In this lifetime calculation of primary income, capital income is excluded. ${ }^{4}$ This is because these incomes are mainly generated from savings out of labour and self-employed income. Savings do not increase the present value of lifetime consumption but largely serve as a vehicle to reallocate consumption across the life cycle. Adding capital income in a lifetime income measure would therefore lead to double counting and an overestimation of lifetime consumption. Depreciation, though included in GDP, is also not included in this measure of income. 5

\section{Advantages and disadvantages of GA in general}

The necessity of evaluating the stance of fiscal policy is the basic problem that lies behind the introduction of the Generational Accounting technique. The technique was first presented in Auerbach et al. (1991). This article followed a long discussion on the use of the government deficit as a measure to evaluate fiscal policies. This debate had underlined that there were several concerns related to the use of the conventional deficit measure. The concerns outlined were mostly related to the inability of the deficit concept to capture some important characteristics of a fiscal policy. ${ }^{6}$ Even though many proposals were made to address those problems, the whole discussion had clearly underlined that the conventional deficit measure was unable to indicate the intergenerational effects of fiscal policies. This is simply because it is a static annual measure and thus incapable of enclosing the full life span of generations. The deficit is not forward looking and it does not capture age specific effects of policies.

Generational Accounting was therefore proposed as a technique to measure the intergenerational effects of policy. The first GA model was developed for the USA by Auerbach, Kotlikoff and Gokhale and was presented in Auerbach et al. (1991). A revised version of the first paper was published in 1994. Within a few years governmental bodies all over the world built GAs for their own countries. In 1999 the book Generational Accounting Around the World was published. It included examples of Generational Accounting models for 22 countries.

Even though Generational Accounting can solve some of the problems related to the use of the deficit, its methodology is not a free of concerns. The introduction of GA in 1991 (Auerbach et al. (1991)) was followed by a long discussion on the reliability of GA results. The main point against GA models was related to the inability of generational accounts to include general equilibrium effects (Haveman (1994) and Buiter 1995)). Every GA model is based on the assumption that factor prices (interest rates and wages) remain constant over time and are independent of fiscal policies. Even though some attempts were made ${ }^{7}$ to show that GA results

\footnotetext{
${ }^{4}$ This applies to both income from both private savings and income from funded private pensions.

${ }^{5}$ As Ablett and Tseggai-Bocurezion (2000) point out, inherited wealth and capital gains that exceed a normal return should, in theory, be included. Both their paper, as ours, however refrain from doing so due to lack of information.

${ }^{6}$ For further details see Auerbach et al. (1999) and Kotlikoff (1992)

${ }^{7}$ See Fehr and Kotlikoff (1999). 
did not differ a lot from the results obtained by using more complex models ${ }^{8}$, this is still today one of the main drawbacks of GA models. At CPB, this problem is tackled by embedding the GA model in an overlapping generations applied general equilibrium model ${ }^{9}$. Other concerns pointed out are the inability of GA models to enclose intergenerational private transfers that could partially or fully offset the intergenerational effects of fiscal policies; the assumption that only the present value of taxes and transfers matters irrespective of their timing which may not be true for liquidity constrained individuals; and finally the problem related to the choice of the right discount factor.

\subsection{Differences with conventional Generational Accounting}

\section{The inclusion of past net benefits}

Lifetime Generational Accounting differs from its conventional counterpart in a number of ways. Conventional GA only includes future net benefits in its calculations. As a result, only the outcomes of the future and newly born generations' net benefits are comparable because, only for those cohorts, net benefits over the entire life span are available. Any comparison among the currently alive generations' net benefits is not possible. This means that generational accounts can not provide information on intergenerational imbalances among the currently alive generations. The latter, however, may be important for political decision making as the effects of most policy measures on these generations differ.

LGA does deliver the full lifetime GAs for current generations by not only including future net benefits, but also past net benefits. Including only the future net benefits would result in an incomplete picture. Moreover, it would even introduce a bias as there are benefiting and contributing stages in the life cycle. For an individual who is 65 years old today, for example, this would mean that the calculations would only cover the years in which he or she has a positive net benefit, mainly due to public pensions and health care, but would ignore the years before in which net benefits were negative (see figure 3.4 in section 3.2).

\subsubsection{Accounting for differences in base year and productivity}

There are two other methodological differences with conventional GA. In conventional forward looking GA, the individual average net benefits of current generations are calculated by discounting the future benefits back to the base year of the exercise (generally the current year or a recent year). However, using the same year entails differences in the stage of the life cycle between these cohorts and, consequently, the calculations impute different discount factors for the same stage of the life cycle. The net benefits in the latest stage of life cycle, say the stage above 80 years, are therefore discounted less heavily for a person aged, for example, 65 than for a younger person. Even with the same time path of benefits during life this would have the

\footnotetext{
${ }^{8}$ These were models that included policy induced general equilibrium effects.

${ }^{9}$ See Draper and Armstrong (2007)
} 
undesirable effect that the outcomes of the present values for older generations would be higher than for the younger ones.

Conventional GA also expresses the GA results in terms of present values rather than as a percentage of lifetime income. For the case of future generations a correction takes place for differences in lifetime incomes by adjusting the results by 1.7 percent (the imputed future annual increase in productivity) for each year that a cohort is born further into the future. However, such an adjustment does not take place for the results of current generations. This does not constitute a clear problem if, as it is the case in conventional forward looking GA, the aim is not to construct comparable full lifetime GAs for the current generations. However, this paper does have this intention and we therefore express the generational accounts as a share of the cohort specific lifetime income.

\section{Differences in the concept of net benefits}

There are three differences between the net benefit concept used in this paper and the corresponding concept generally used in GA and LGA exercises:

1) The first difference is somewhat trivial. Auerbach et al. (1991) perform their analysis in terms of net taxes rather than net benefits. This only involves a difference in sign.

2) In contrast to Auerbach et al. (1991), this paper also assigns the benefits from non-cash benefits and from pure public goods to age groups and thus makes these benefits form part of the age profiles. The age profile of net benefits, as computed here, therefore, includes the assigned benefits from these goods whereas the net tax concept in Auerbach et al. (1991), and most of the other GA and LGA studies, does not.

3) In contrast to GA and other LGA studies this paper distinguishes between government investments and government consumption. The benefits of the accumulated past investments form part of the net benefit concept as explained in section 2.1.1. 


\section{Data and assumptions}

\subsection{An insight into past government finances}

\section{Past annual budgets}

The derivation of lifetime generational accounts requires historical data on government revenues and expenses. For our analysis we made use of CPB data ${ }^{10}$ on government revenues and expenses. Past capital stocks and the depreciation rates applying to the public capital stock have been provided by Statistics Netherlands. ${ }^{11}$

Table 3.1 provides an overview of the development of past expenditure and revenue in the period 1950-2007. This subsection is added in order to provide an insight in past government policies and, in this way, to provide background information that could help to understand the outcomes of the LGAs which will be presented in the next section. The table shows that there have been large changes in both the size and the composition of the public sector during that period. Total expenditure increased substantially in the first decades. Between 1950 and 1983 expenditure grew by almost 30 percent of GDP. The main contributors to this development were government transfers, health care, education, general government and other primary expenditure (mainly subsidies and transfers abroad).

In the period 1983-2007 public expenditure declined by 15 percent of GDP. The largest decrease, in terms of percentage points, was in government transfers and other primary expenditure. This was the result of a government policy to get public finances in order, after a period of rising deficits, as well as the consequence of a shift towards a view on the working of the economy that recognizes the importance of financial incentives on labour supply and investments. In this period, expenditure on education also declined as a share of GDP, largely due to falling birth rates. The drop in defence expenditure followed international developments in the form of the demise of the Warsaw Pact. Against this trend, health care expenditure continued to rise.

Total government revenues showed a time pattern that was similar, though less extreme, than expenditure. The pattern is most specifically present in the case of income taxes and social security premiums and non-tax revenues (mostly consisting of revenues from government financial assets, government sales, subsidies from the EU and revenues from natural resources). Corporation taxes and taxes on dividends however showed the opposite pattern. This is also the case for indirect taxes. After a drop in revenue in the 1950's it rose continuously in the decades thereafter.

\footnotetext{
${ }^{10}$ These data are publicly available on the CPB web site (http://www.cpb.nl/nl/data/tijdreeksenoverheidsfinancien.xls) and already used in Bos (2006).

${ }^{11}$ Both the public capital stock and the depreciation rates are differentiate between infrastructure, government buildings and school buildings.
} 


\begin{tabular}{|c|c|c|c|c|c|c|c|}
\hline \multirow[t]{2}{*}{ Government expenditure an } & nues in & $50-200$ & $\%$ GDP & \multirow[b]{2}{*}{1983} & \multirow[b]{2}{*}{1990} & \multirow[b]{2}{*}{2000} & \multirow[b]{2}{*}{2007} \\
\hline & 1950 & 1960 & 1970 & & & & \\
\hline Defence & 3.9 & 3.3 & 2.7 & 2.9 & 2.4 & 1.3 & 1.2 \\
\hline General government & 8.3 & 9.6 & 10.6 & 12.2 & 11.7 & 11.6 & 11.9 \\
\hline Infrastructure & 2.4 & 2.5 & 2.6 & 1.5 & 1.5 & 1.6 & 1.6 \\
\hline Health care & 0.9 & 1.3 & 2.7 & 4.8 & 5.3 & 6.0 & 8.8 \\
\hline Education & 2.9 & 4.8 & 6.3 & 6.3 & 5.6 & 4.8 & 5.0 \\
\hline \multicolumn{8}{|l|}{ Transfers } \\
\hline Public pensions & 0.9 & 3.1 & 4.7 & 6.0 & 6.3 & 4.9 & 4.7 \\
\hline Other transfers & 4.5 & 4.7 & 6.7 & 14.0 & 11.1 & 6.3 & 6.1 \\
\hline Other primary expenditure & 4.9 & 4.1 & 5.0 & 7.2 & 6.5 & 4.8 & 3.9 \\
\hline Interest payments & 3.6 & 2.8 & 2.9 & 5.5 & 5.8 & 3.7 & 2.2 \\
\hline Total expenditure & 31.9 & 36.2 & 44.3 & 60.4 & 56.1 & 45.0 & 45.4 \\
\hline \multicolumn{8}{|l|}{ Non-tax revenues } \\
\hline Revenues from natural resources (gas) & 0 & 0 & 0.2 & 3.4 & 1.1 & 0.7 & 1.4 \\
\hline Other revenues from government sales & 12.2 & 6.6 & 7.5 & 9.1 & 8.0 & 6.4 & 5.5 \\
\hline Total net expenditure & 19.7 & 29.6 & 36.6 & 47.9 & 47.0 & 37.9 & 38.5 \\
\hline Income taxes and social security contributions & 16.0 & 18.8 & 22.3 & 29.4 & 26.3 & 22.2 & 21.4 \\
\hline Indirect taxes & 10.8 & 8.0 & 11.1 & 11.5 & 12.1 & 13.3 & 13.8 \\
\hline Corporation taxes and taxes on dividends & 4.3 & 3.6 & 2.6 & 1.6 & 3.3 & 4.4 & 3.7 \\
\hline Total taxes & 31.1 & 30.4 & 36.0 & 42.5 & 41.7 & 39.9 & 38.9 \\
\hline Government deficit & -11.4 & -0.8 & 0.7 & 5.5 & 5.3 & -2.0 & -0.4 \\
\hline Government debt & 154 & 75 & 49 & 60 & 77 & 54 & 46 \\
\hline
\end{tabular}

\subsubsection{Translating annual budgets into annual net benefits}

Further relevant underlying information is provided by annual aggregate net benefits. This variable measures the sum of net benefits received each year. It shows high positive values over the last decades. This is a major explanatory factor behind the high positive values of the individual LGAs that we will present in the next section. As already explained in section 2, generational accounting was originally introduced as a technique to deal with the problems related to the interpretation of the deficit. It introduced a forward looking and dynamic approach that is designed to calculate generation specific effects. However a simpler and more transparent analysis of how annual net benefits have developed over time may also provide an intuitive insight in the major contributors to these high positive benefits. It is important to realize that the annual net benefits from government deviate from the government deficit, the difference between government expenditure and revenues, due to the fact that not all expenditure items are counted as a benefit and not all revenue items are counted as a burden.

Moreover, we impute seigniorage as a burden. Combining the definition of net benefits as stated in equation (2.1): 


$$
N B=C+I B C+T R-T-S
$$

and that of the government deficit:

$$
D E F=C+T R+I+R E-T-R R-G A S
$$

we can redefine the net benefit as:

$$
N B=D E F+(I B C-I)+G A S+(R R-R E-S)
$$

In (3.2) and (3.3) $I, G A S, R R$ and $R E$ respectively stand for government investments, revenues from natural resources (mainly gas), revenues from government held financial assets and government expenditure on interest payments. In equation (3.3), the net benefit concept consists of four components: the deficit; the difference between the imputed benefits from the public stock of physical capital and investments; gas revenues, which is a source of revenue for the government but does not form a burden for the private sector as the payment for the gas delivery involves an exchange in return; and an item that corrects for revenues from financial assets and interest payments (both also involving an exchange in return, and thus not counted as either a burden or a benefit) and corrects for seigniorage (not a revenue for the government, but counted as a burden for citizens).

Figure 3.1 shows how annual net benefits and its four components have developed between 1950 and 2007. It shows that past developments of net benefits were even more marked than those of the deficit. In order to understand what lies behind past developments in aggregate net benefits, figure 3.1 provides a decomposition. It shows that annual net benefits were very low in the first years, reflecting the large government surplus of the time. As the surplus became lower as from the mid fifties, also net benefits increased. The two variables remained relatively close to each other, and close to zero, for the years up to 1975. Small deficits in this period were typically accompanied by small negative net benefits due to (imputed) benefits from the public capital stock that were lower than investments, and small net interest payments. As from 1975 however both the deficit and revenues from gas jumped, leading to a period of very high net benefits. Lower public investments and a gradually increasing benefit from the public capital stock due to past investments, slightly contributed to this development. In 1982 net benefits even peaked at a level of more than 10 percent of GDP.

After 1982 the opposite development took place. Fiscal austerity measures, necessary to consolidate government finances, had to take place in a period of falling revenues from gas and, due to rising debt levels, increasing net interest payments. This aggravated its effect on net benefits. The consolidation was achieved by a large decrease in primary expenditure. As a 
result, net benefits dropped sharply and even became negative in the late 1990 's ${ }^{12}$. In 2000 , the deficit had also turned into a surplus. After 2000, net benefits rose again as government policies were relaxed and falling interest payments created room to increase net benefits, mainly by raising expenditure on health care.

\section{Figure 3.1 Aggregate annual net benefits and its components in 1950-2007 (\% GDP)}

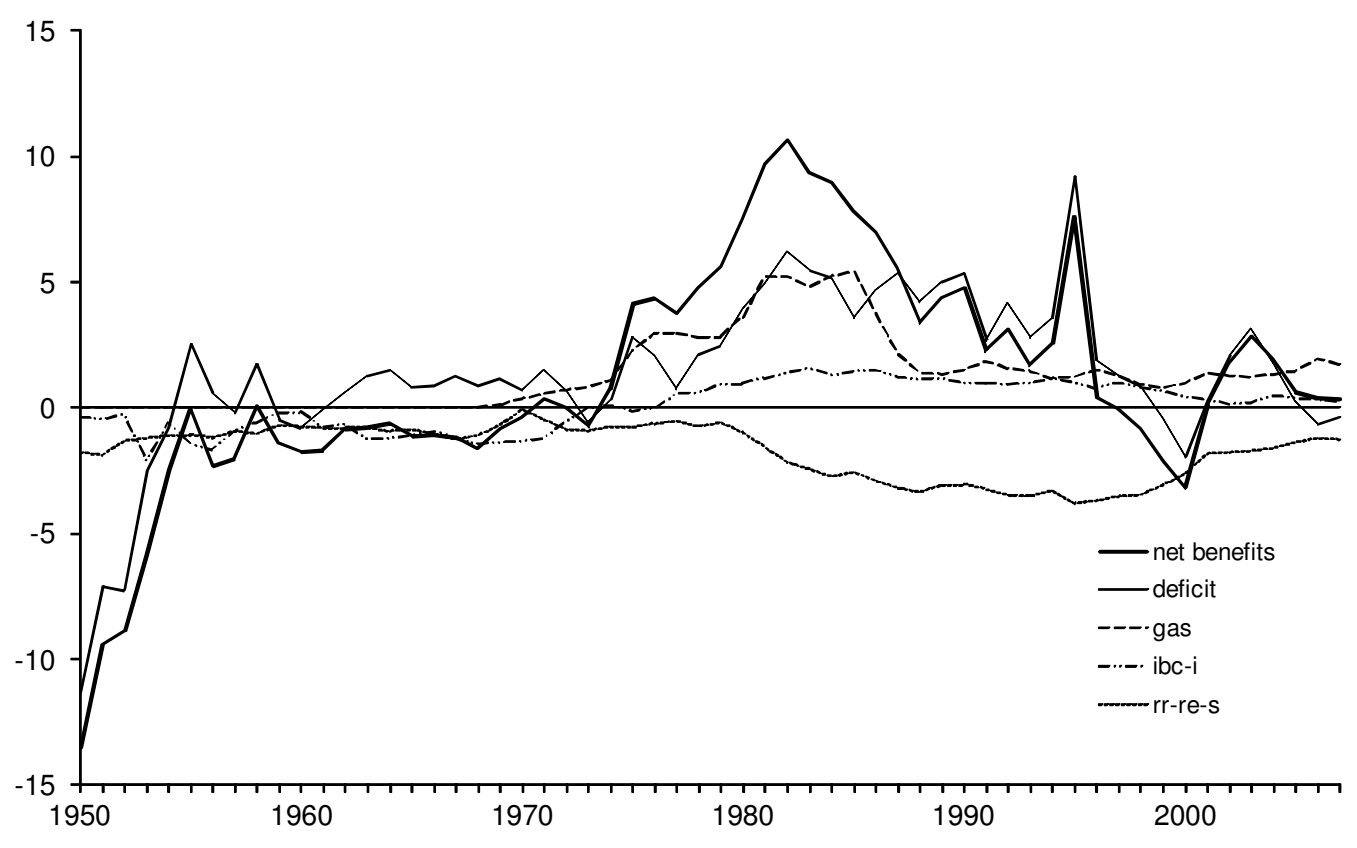

\subsection{Current age profiles}

In order to spread aggregate annual net benefits over different age groups, age profiles of taxes and transfers have been used. Section 3.3 discusses how age specific net benefits are constructed for future and past years. These are based on the current age profiles of each of the items of which the net benefit concept is composed of. Figures 3.2, 3.3 and 3.4 presents an overview of these current age profiles. They illustrate how annual average individual benefits and burdens, as well as annual net benefits, are distributed across age groups. Figure 3.2 shows the age profile of total benefits, benefits from health care and transfers for 2008. It shows that age specific total benefits are highly dependent on age. At the age of 65 , when the eligibility for the public pension starts, benefits from transfers increase sharply. Benefits from health care show a continuous rise. As from the age of 80 health care forms the major part of benefits (mainly in kind). Below the age of 25 the age profile is mainly shaped by the benefits from expenditure on education between the age of 5 and 25. The other benefits from government expenditure, such as from general government, infrastructure and defence, are, by assumption, distributed uniformly across all citizens. These are the pure public goods, or the 'classical'

\footnotetext{
${ }^{12}$ The peak in both the deficit and net benefits in 1995 is the result of a one off redemption by the government of future annual subsidies to housing corporations.
} 
government expenditure items. The benefits of these items can not be directly attributed to individuals.

\section{Figure 3.2 Age profile of average benefits from government in 2008 (in thousands of euros)}

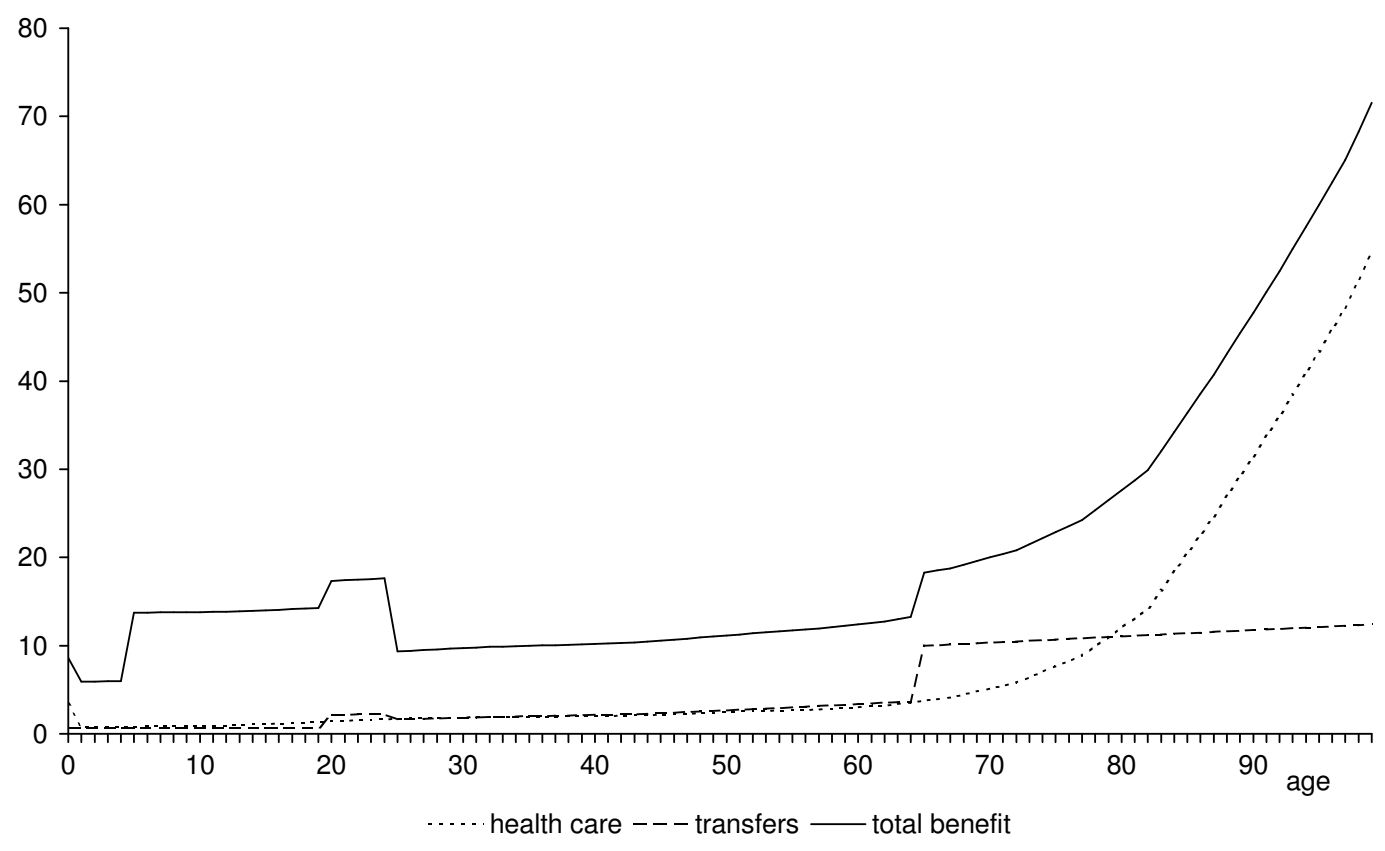

Figure 3.3 Age profile of average tax burden in 2008 (in thousands of euros)

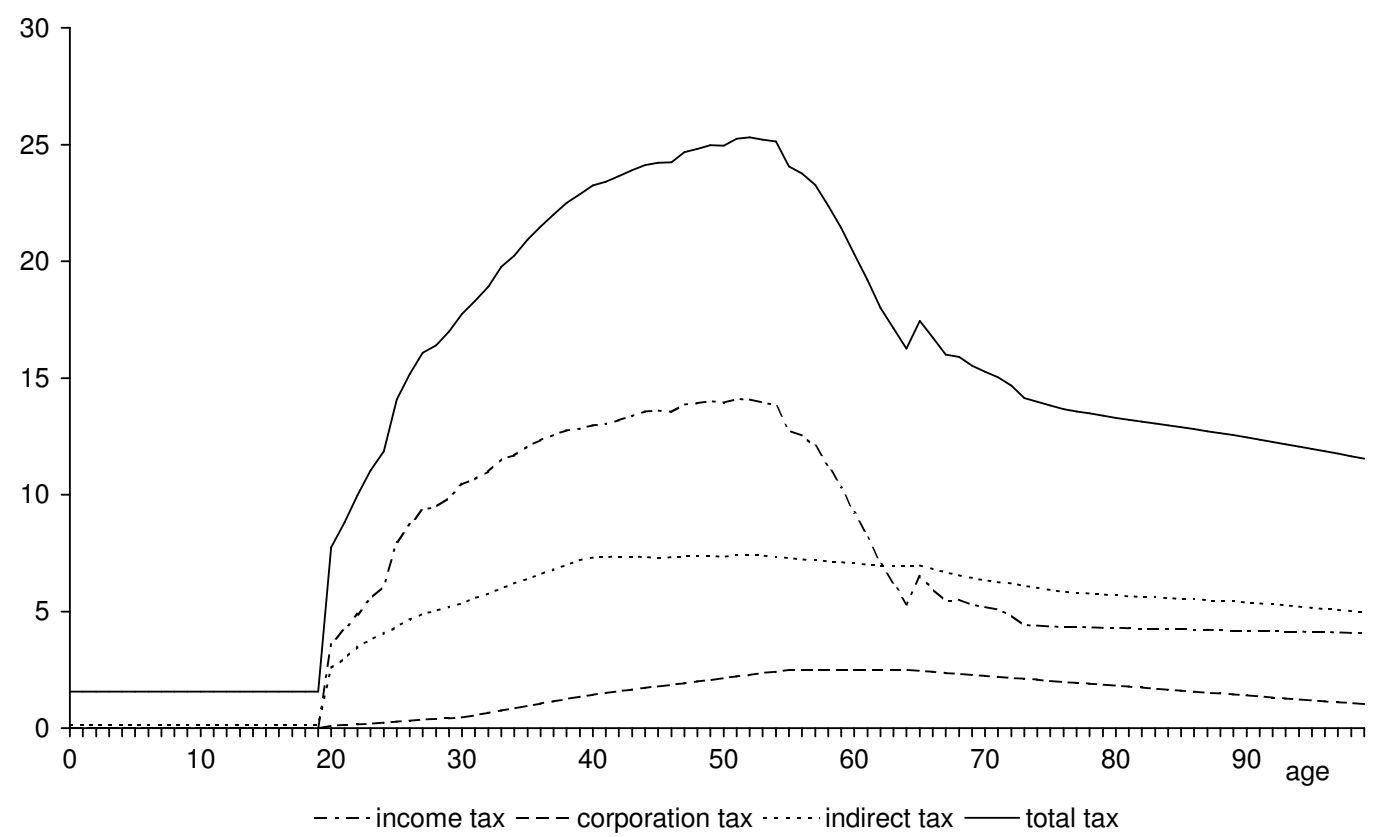


Figure 3.3 presents the age profile of the total tax burden, and its decomposition in the burden from income taxes, corporation taxes and indirect taxes for 2008. It shows a sharp rise between the ages of 20 and 40 when people start to participate on the labour market and have rising income levels. After the age of around 55 the tax burden declines due to falling levels of labour participation and the fact that the tax rate for pensioners is significantly lower than for workers. The age profile of indirect taxes is flatter because households smooth their consumption across the life cycle and rates of taxation are assumed equal for all ages. The profile of the corporate tax reflects asset holdings across age groups.

Figure 3.4 presents the age profile of net benefits. It is the difference between the total benefits from expenditure and the total burden from taxation. Below the age of 25 and over the age of 65 the average citizen turns out to be a net beneficiary from government. People below 25 benefit from education, child allowances, health care and general government, while only paying little taxes. As from the age of 25 they, on average, become net contributors. Mainly in the form of income taxes, social security contributions and indirect taxes they pay more than they receive in the form of income transfers and benefits in kind. From the age of 65 onwards net benefits are positive again because of lower tax rates and the fact that people become eligible for the public pension and increasingly benefit from health care.

\section{Figure 3.4 Age profile of average net benefit in 2008 (in thousands of euros)}

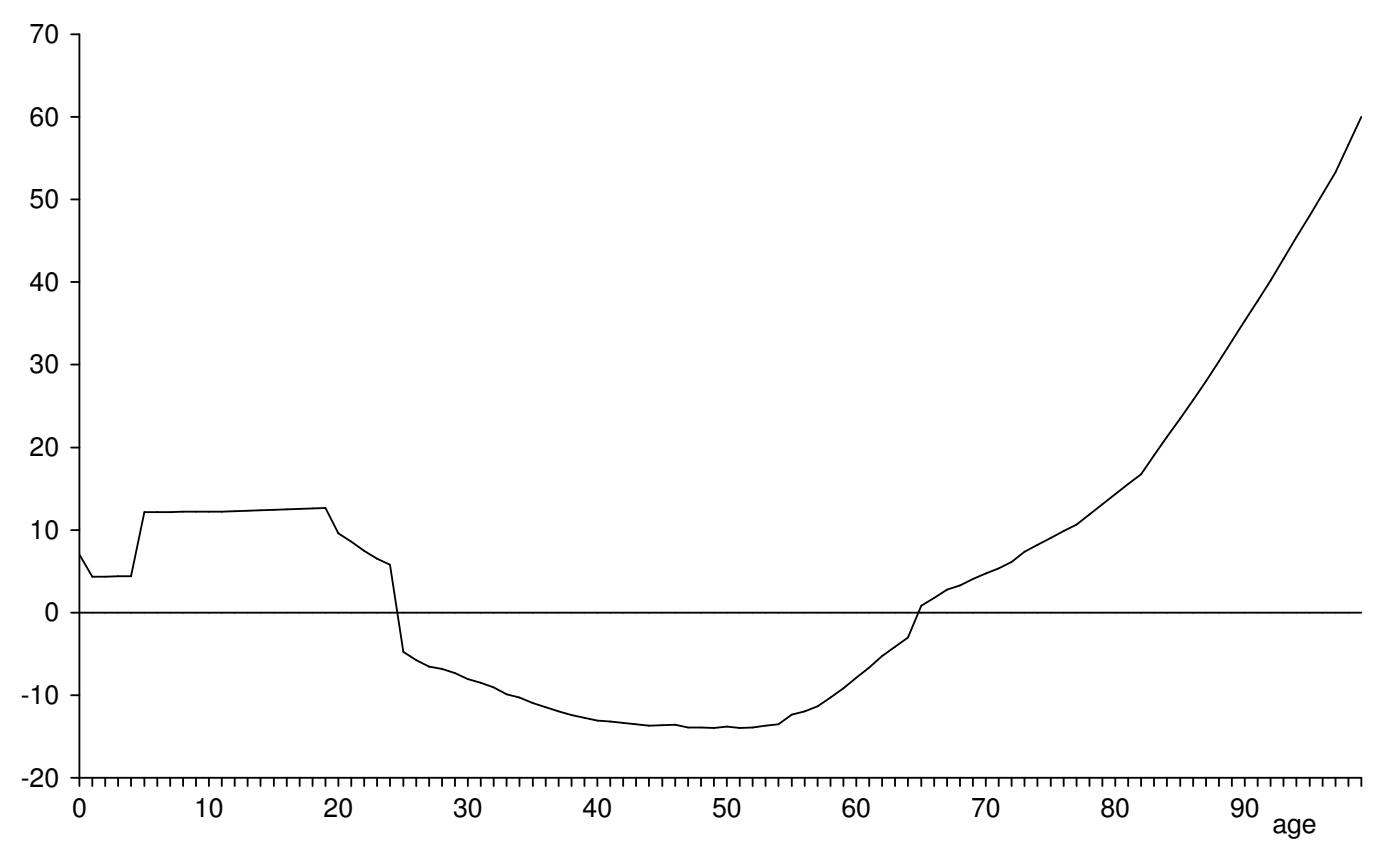


Some of the items presented in Figures 3.2 and 3.3 are themselves composed of several expenditure or tax items. Direct and indirect taxes are split into taxes on wages, pensions, social security and capital. Each one of these sub-items has its own age profile. Among the expenditure items the same applies to transfers which can be subdivided into public pensions, disability benefits, unemployment benefits and social assistance as well as health care that can be subdivided into cure and long term care. ${ }^{13}$

As explained in section 2, generation specific individual net benefits have been derived by first computing generation specific individual benefits or burdens for each sub-item separately. Following the definition of net benefits as presented in equation (2.1) the generation specific individual net benefits have been derived. All the details on the procedure followed to derive the age profiles can be found in the appendix that is published with this paper.

\subsection{Past and future age profiles}

\section{Constructing age specific net benefits}

Equation (2.3) shows that we need data on the population, on age specific net benefits and on lifetime incomes to carry out the exercise. This involves projections into the future as well as, for the currently living generations, historical data. As regards the population, we use the data that are provided by Statistics Netherlands (CBS). As regards the age specific net benefits, we construct these from historical data and projections on each of the items of which the net benefit concept is composed of. This requires a distinction between the past and the future.

In making future projections for public expenditures and taxes, we make the basic assumption that expenditures and revenues are indexed to productivity growth. We differentiate between expenditure items of which the benefits can be directly attributed to age groups on the basis of micro data, such as education, social security and health care, and the items for which this is not the case such as defence and general government. For the latter items we assume that expenditure is linked to GDP and that the benefits in each year accrue equally to all individuals. With respect to the former items, we assume that age-specific benefits are indexed to wages. The distribution across age groups is based on its current distribution, reflected in the age profile of the item, and is constructed from various sources of data regarding the specific item.

On the revenue side, average tax rates are held constant. Accordingly, aggregate tax receipts will change only via changes in the tax base. With respect to income taxes, the current distribution across age groups equals the distribution of incomes. With respect to consumption taxes, we assume that private consumption is determined by consumption smoothing, whereby

\footnotetext{
${ }^{13}$ These age profiles are derived from various sources. The profile for health care consists of the profiles for cure and care, which are both based on information provided by the RIVM (2007). The age profile for the disability benefits are based on Van Sonsbeek en Alblas (2010), as is the future use of this government program. The profile for public pensions is based on its institutional arrangement. It is granted to individuals as from the age of 65 . Being a flat rate system, only granting a higher benefit to singles than to married individuals, it is imputed to rise slightly with age due to an increasing share of single households. The profile for unemployment benefits and social assistance are assumed flat between the ages of 20 and 64 due to lack of information.
} 
young people save to finance consumption at old age. ${ }^{14}$ Seigniorage is assumed to amount to $0.18 \%$ of $\mathrm{GDP}^{15}$, to grow in line with consumption spending of households and to be distributed over age groups accordingly. ${ }^{16}$

Past age specific net benefits are constructed by combining historical data on the aggregates of each of the items ${ }^{17}$ with their corresponding age profile. The best practice would be to use a different age profile for each year. The construction of year specific age profiles, though, would require very detailed historical micro data. These are not available. In our analysis we generally made use of time invariant age profiles ${ }^{18}$. These profiles are discussed in section 3.2. By doing that, we implicitly assumed that the relative size of the individual net benefits across all age groups remained constant. Only the profiles of education and wage taxes have been modified. The former to take into account the fact that less people attended higher education before 1980. ${ }^{19}$ The latter was modified to take account of diverging past age specific labour participation rates.

Net benefits for each year and age group are subsequently calculated as the balance of all benefits and burdens. This results in a matrix of net benefits for each age group and for each year as from 1946. As we project for 200 years into the future and assume a maximum length of life of 100 years, this enables us to construct LGAs for all cohorts born as from 1946 until base year 2008 as well as for the first 100 of the cohorts born after 2008 .

\section{Constructing age specific incomes}

The construction of age specific incomes for each year, which is necessary to construct the $L I_{s, k}$-variable, is similar to the way this is carried out for net benefits. Here too, we use the current distribution across age groups as the basis to construct both their future and the historical counterparts. The current distribution is arrived at by spreading out the aggregate pretax primary income across age groups based on information on the demography, age specific wages and rates of labour participation. Indirect taxes are added proportionally. Here too, we distinguish between the past and the future. Future age specific primary incomes are projected to rise in line with the increase in labour productivity and changes in age specific labour force participation. ${ }^{20}$ For the past we use the realized aggregates of primary income of each year as a starting point. These are spread out across age groups in line with the population numbers, the

\footnotetext{
${ }^{14}$ See Alessie and De Ree (2009)

${ }^{15}$ This is based on current private holdings of notes and coines.

${ }^{16}$ For more details on the construction of age profiles and the projection of expenditure and revenues see Van Ewijk et al. (2006).

${ }^{17}$ With respect to the IBC-variable we use data on past capital stocks (physical assets) and the depreciation rates on these stocks.

${ }^{18}$ This means that only the shape of the profile remains unchanged. The absolute size of it was adjusted in each year in order to equal the correct aggregate of the expenditure or revenue item.

${ }^{19}$ This is explained in section 6 .

${ }^{20}$ The imputed age specific changes in labour participation are based on Euwals and Folmer (2009). For the annual increase in labour productivity we follow the European Commission (2009) and Van der Horst et al. (2010) by imputing 1.7\% annually.
}

20 
age-specific rates of labour participation and age specific wage rates that we impute for that year. For the first two of these, historical data are available. For the age specific wage rates however, there are no historical data available and we had to resort to using the current pattern of relative wages across age groups.

\section{The discount rate}

The discount rate has been set at 3\% in real terms. This is the same rate as used in Van Ewijk et al. (2006), European Commission (2009) and Van der Horst et al. (2010). As explained in Van Ewijk et al. (2006), it is higher than the real rate of interest on government debt. This is because it takes into account that over a long time horizon government revenues and expenses are risky because they depend on economic growth. The 3\% real discount rate is assumed constant between 1946 and 2007, as it is for the future. ${ }^{21}$ By imputing a uniform discount rate for future and past we follow the other LGA studies in the world (see section 7).

\footnotetext{
${ }^{21}$ The best practice might be to impute a different real discount rate for each year between 1946 and 2007. However, this would have required past data on short-term government papers that are not directly available for a such long period as well as an estimate of past risk premiums.
} 


\section{$4 \quad$ Baseline results}

\subsection{The Lifetime Generational Accounts (LGAs)}

The presentation of full lifetime LGAs requires that assumptions are made on future government policies over a long period of time. As we want to present comprehensive and feasible LGAs, it is necessary to impute sustainable government policies. Not doing so would entail that the computed future net benefits would not be a correct representation of actual future policies as it would not obey the inter-temporal budget restriction. CPB studies (see Van der Horst et al. (2010)) have pointed out that current policies, defined here as the policy that was in place in June 2010 and thus not including later changes, are not sustainable and that substantial adjustments are required to achieve sustainability. These studies arrive at a sustainability gap of $4 \frac{1}{2} 2$ percent of GDP. This means that achieving sustainability requires a short term cut in expenditure or rise in taxation, or a combination of these, that amounts to $4 \frac{1}{2}$ of GDP and remains constant thereafter, or an equivalent thereof in terms of present values. We will present the LGAs of five ways of arriving at sustainable policies ${ }^{22}$ which are discussed in Van der Horst et al. (2010) and cover a wide range of possibilities of achieving sustainability. ${ }^{23}$ In order to present their effects, we add the LGAs of the current, unsustainable, policy.

The five sustainable policies are:

1) A cut in expenditure on general government of 41/2 percent of GDP in 2015.

2) A cut in all expenditure items by 9.2 percent in 2011 .

3) A rise in indirect taxes in 2015 by around one third.

4) A mix of policies that are implemented gradually. These involve a rise of the pension age by four steps of one year (to 69 years), a rise in the taxation of pensioners, a shortening of the period of eligibility to unemployment benefits, a measure that curbs the inflow into the disability scheme of the young, and a rise of indirect taxation by 23 percent.

5) A strongly delayed adjustment of policy. Policy is made sustainable not before 2040 by curbing general government by 6.1 percent of GDP. In this scenario government debt eventually reaches a level of 180 percent of GDP. This policy is therefore not considered to be a reasonable option. It is only included for the analytical purpose of presenting the intergenerational effects of a strong delay.

Figure 4.2 shows the LGAs of the five sustainable scenarios and of the current unsustainable policy. They present the lifetime net benefits as a percentage of lifetime income, as specified in

\footnotetext{
${ }^{22}$ A policy is considered sustainable if after 200 years, the time horizon of our model, government debt remains constant as a share of GDP. All variables then show a more or less steady state development.

${ }^{23}$ This paper ignores the measures that were decided on after June 2010 . These measures reduce the sustainability gap by $31 \frac{1}{2}$ percentage points to 1 percent of GDP. Including these measures would however not change the intergenerational picture presented in Figure 4.2 as this only means that (part of) the sustainability measures are now filled in.
}

22 
equation (2.3). The figure shows that the LGAs of the four reasonable sustainable scenarios (scenarios 1 till 4) show a similar pattern suggesting that the choice of policy to render public finances sustainable does not seem to matter much for the overall picture. The results show that in all scenarios almost all cohorts born since 1946 benefit from government. This is made possible by the government revenues from natural resources (gas), and by the fact that there are strong indications that the cohorts born before 1946 have been net contributors to public finances, and thus feature negative net benefits (section 4.2). Apart from the scenario with a strongly delayed adjustment, also the very first of the post-war cohorts in our measurements show negative net benefits. However, net benefits rise sharply in all scenarios for the younger cohorts, becoming positive as from the cohort born around 1948, and reach a peak for the cohorts born between 1960 and 1990. This peak ranges from 8 to $10 \%$ of lifetime pre-tax income. It is lowest for the policy scenario in which the adjustment is implemented gradually (scenario 4), reflecting the fact that this variant most specifically targets these cohorts by adjusting policy in a way that heavily affects the late stage of the life cycle. These cohorts still have this stage ahead of them. The peak is higher in the scenarios in which policy is adjusted more quickly, in the short to medium term (scenarios 1, 2 and 3), but wherein the policy change more equally affects all stages of the life cycle. This indicates that the stage of life has an important weight in determining the outcomes. Unsurprisingly the peak is highest, at around $10 \%$ of lifetime income, in the (unrealistic) scenario in which the adjustment is delayed until 2040 (scenario 5).

In all scenarios, net benefits decline for the cohorts born after around 1990. This results from the fact that the current system of public finances is unsustainable and large adjustments are necessary, leading to cuts in expenditure and/or higher taxes. The younger the cohort, the more they are affected. Our measurements nonetheless show that in the reasonable scenarios net benefits will remain positive, at $1 \frac{1}{2} 2$ to $2 \frac{1}{2} \%$ of lifetime income, for even the very youngest of the currently living cohorts as well as for future cohorts. Net benefits for these cohorts are highest in the scenario in which the policy change most affects the late stage of the life cycle (scenario 4), because this adjustment weighs less heavily in a lifetime present value calculation. Nonetheless, the overall outcome of the LGAs turns out to be relatively robust for the various ways in which the system of public arrangements can reasonably be adjusted in order to achieve sustainable public finances and the policy adjustment is not delayed for very long. In the scenario with a strong delay in the policy adjustment net benefits become negative as from the cohort born in 2036 .

Figure 4.1 also shows that even in the exercise that imputes unsustainable current policies, net benefits of cohorts born after 1990 turn out to be lower than that of the older cohorts. ${ }^{24}$ This points out that past budgetary measures have an intergenerational effect, which is due to the fiscal austerity measures which became effective after 1982.

\footnotetext{
${ }^{24}$ In Van der Horst et al. (2010) we presented the annuity value version of this figure for the case in which sustainability was arrived at by curbing expenditure in general government.
} 


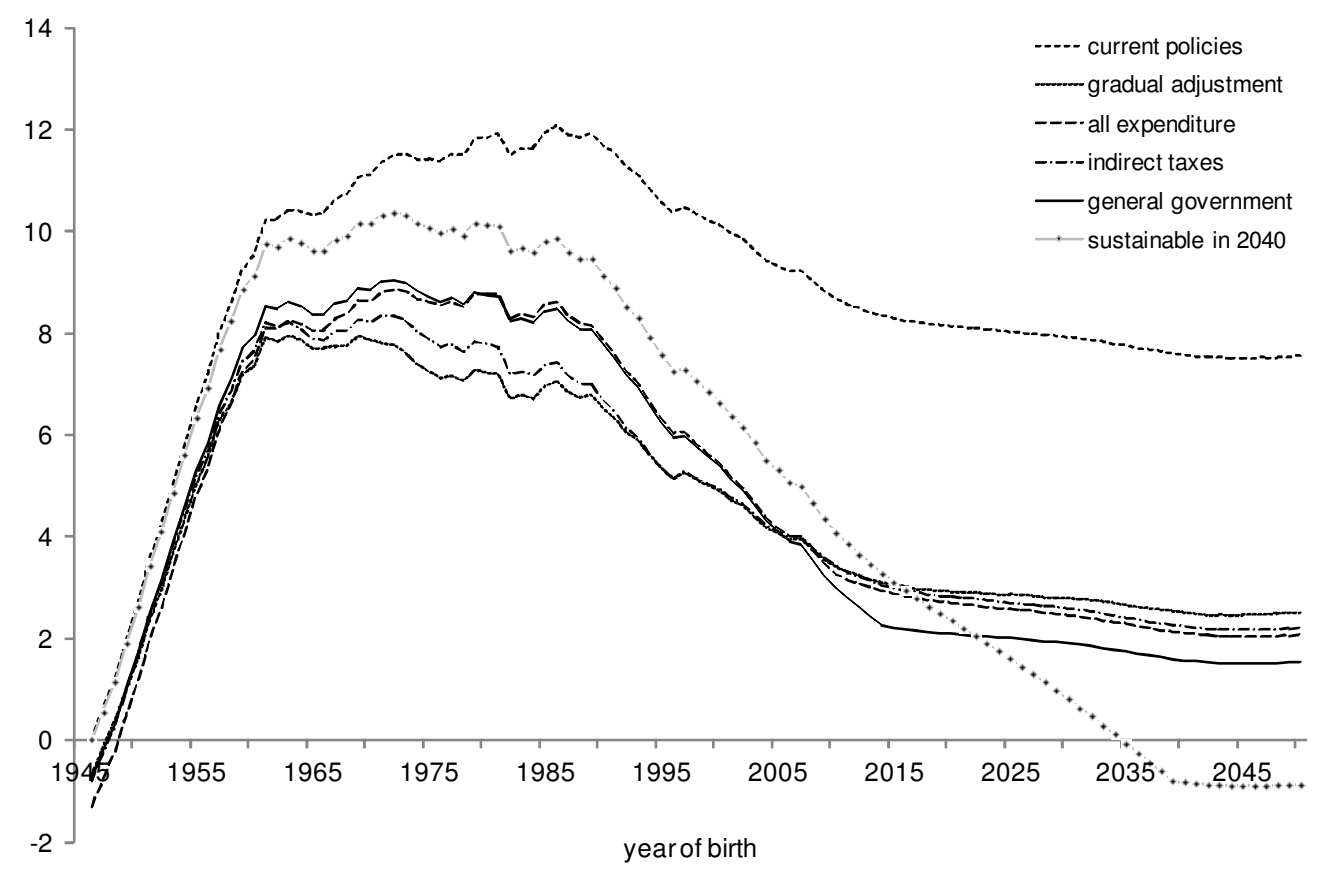

Table 4.1 decomposes the result into its past and future contribution. This is done for the scenario in which policy is made sustainable by curbing general government.

\begin{tabular}{|c|c|c|c|c|c|c|}
\hline \multicolumn{7}{|c|}{ Contribution of future relative to past } \\
\hline Year of birth & 1946 & 1958 & 1970 & 1982 & 1995 & 2008 \\
\hline \multicolumn{7}{|l|}{$\%$ of lifetime income) } \\
\hline \multicolumn{7}{|l|}{ of which: } \\
\hline before 2008 & -9.1 & 6.0 & 16.8 & 22.2 & 10.4 & 0 \\
\hline as from 2008 & 8.4 & 1.1 & -8.0 & -14.0 & -4.1 & 3.5 \\
\hline
\end{tabular}

The net benefits of cohorts as presented in figure 4.1 are generally larger than the annual net benefits that were presented in figure 3.1. There are two reasons for this. The first lies in the fact that the net benefits of cohorts are expressed as a percentage of primary income as defined in this paper (see subsections 2.1.2 and 3.3.2), whereas the annual figure of net benefits were, following conventional practises, presented as a percentage of GDP. The latter forms a far broader measure of income. It includes capital income and depreciation as well, and is about $50 \%$ larger than the primary income measure used in the denominator for the presentation of the benefits of cohorts. The second reason for the higher results in the case of the presentation of the cohort effects lies in the fact that cohorts born before 1946 probably feature negative net benefits which are included in the annual presentation but excluded in the cohort presentation. 


\subsection{The origins of the positive net benefits}

The generally positive net benefits for the cohorts born as from 1946, with only the first two of these featuring negative benefits, can be explained by:

a) The windfall gain from the revenues from natural resources

b) Negative net benefits (net contributions) by cohorts born before 1946

c) Possibly net interest payments on net debt that have, on average and ex post, turned out to bear a lower rate of interest than the 3 percent in real terms that is imputed in the lifetime present value calculation.

This sub-section performs a decomposition of total net benefits of all cohorts born as from 1946 into component a and the combined effect of components $\mathrm{b}$ and $\mathrm{c}$. Components $\mathrm{b}$ and $\mathrm{c}$ have to be combined because we lack the data to determine them separately. The calculation is carried out for sustainable scenario 1 . This is done by first calculating the total present value, in base year 2008, of the net benefits of the cohorts born as from 1946, including those of the future cohorts. Table 4.2 (upper row) shows that the sum of these amounts to 1789 bln euros. The second row shows that the present value of the revenues from natural resources, extracted in both the past and the future, adds up to 651 bln euros. As a share of the total net benefits of these cohorts this is $36 \%$. Residually it can then be calculated that the present value in 2008 of components b and c combined equals 1138 bln euros, or $64 \%$ of the total net benefits. It seems plausible, from Figure 4.1, that the net contribution of earlier cohorts forms a substantial part of it. Figure 4.1 shows that net benefits of the 1946-cohort is negative and dropping sharply for older cohorts.

\begin{tabular}{lrr}
\hline Table 4.1 Decomposition of cause of the positive net benefits & & \\
& In bln of euros (present & As percentage of total \\
& values in 2008) & 100 \\
Total net benefits of all cohorts born as from 1946 & 1789 & 36 \\
Resulting from: & 651 & 64 \\
Natural resources (gas) & 1138 & 36 \\
Net contribution of earlier cohorts and low net interest payments & & \\
\hline
\end{tabular}




\section{$5 \quad$ A decomposition}

This section performs a decomposition of the results. This provides an insight in the items in the government budget that determine the outcomes. The decomposition is carried out for the case wherein government policy is made sustainable by curbing general government by $4 \frac{1}{2} \%$ of GDP (scenario 1).

Figure 5.1 shows how lifetime benefits and tax burdens are distributed across generations under current policies. It shows that, as far as past policies are concerned, the movements in net benefits can be almost fully attributed to changes in benefits, i.e. the expenditure side of the government budget. Benefits rise sharply from $56 \%$ of lifetime income for the oldest cohorts to around $65 \%$ of lifetime income for the cohorts born in 1960. It remains roughly constant until the cohorts born around 1990 before declining again for the later cohorts. Eventually, it stabilizes at around 57\%. The tax burden remains fairly constant at around 55 to $57 \%$ of lifetime income. This reflects the relative constancy of the tax to GDP ratio as from around 1970 (see table 4.1) when the oldest of the cohorts considered in this paper started to participate on the labour market and started to pay taxes.

\section{Figure 5.1 Lifetime benefits and tax burdens under scenario 1 (as a percentage of lifetime income)}

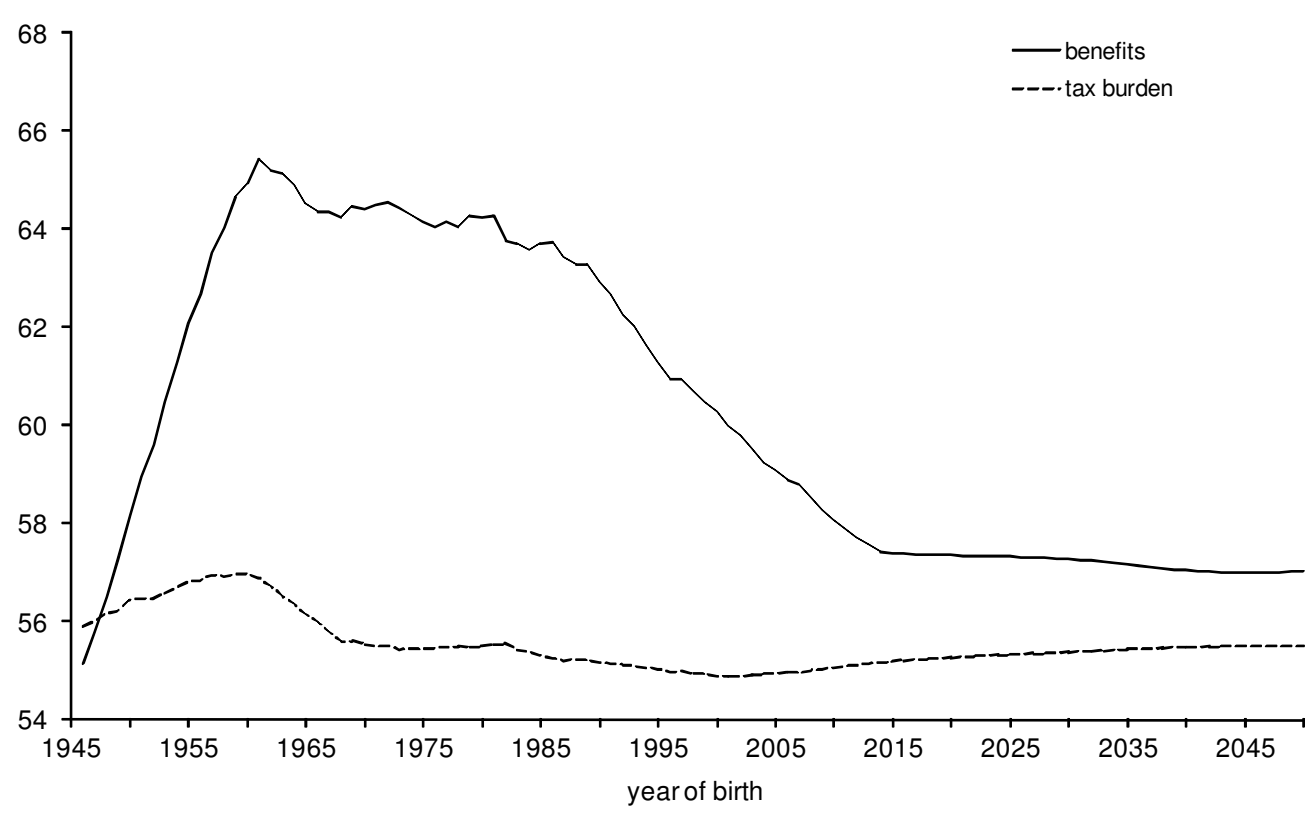

These lifetime tax and benefit rates are generally substantially higher than their annual equivalents in Table 3.1..$^{25}$ The reason for this is that the annual figures are expressed as a percentage of GDP whereas the lifetime generational figures are expressed as a percentage of lifetime incomes. The latter measure of income is smaller because it excludes capital income (see section 2.1.2), thereby raising the ratio. The same obviously applies to the individual items

${ }^{25}$ These annual equivalents in Table 3.1 are 'Total taxes' and 'Total net expenditure' .

26 
which are discussed below. Another reason for differences between the LGAs and the annual figures lies in the fact that the former is influenced by the stage in the life cycle in which the benefit or tax burden occurs. Note that these are present values. This applies especially to the individual items. Items of which the benefits occur early in the life cycle, such as education, therefore turn out relatively high in the generational figures whereas late in the life cycle items, such as health care, come out relatively low.

Figures 5.2 and 5.3 perform a breakdown of lifetime benefits. In figure 5.2 the breakdown is carried out for the expenditure items of which the benefits can be attributed to separate individuals. These are referred to here as the 'welfare state' items. The most striking result here is the enormous rise of the benefits from education between the cohorts born in 1946 and those born around 1965. Benefits actually double from around 5\% of lifetime income to around $10 \%$. For the younger cohorts there is a small further rise to around $11 \%$. There is also a marked and constant rise in lifetime benefits from health care from around $11 \%$ for the oldest cohort to 15 $\%$ for the very youngest and unborn cohorts. These developments are mainly a reflection of the expenditure pattern as presented in table 4.1. There is also a, more moderate, rise in lifetime benefits from public pensions. ${ }^{26}$ This results from increasing life expectancies. Lifetime benefits from other transfers (disability, unemployment and social assistance) show a drop from $12 \%$ of lifetime income to $10 \%$ between the cohorts born around 1960 and 1975 due to the austerity measures enacted between 1983 and the first years of this century.

Figure 5.2 Lifetime benefits of 'welfare state' expenditure items under scenario 1 (as a percentage of lifetime income)

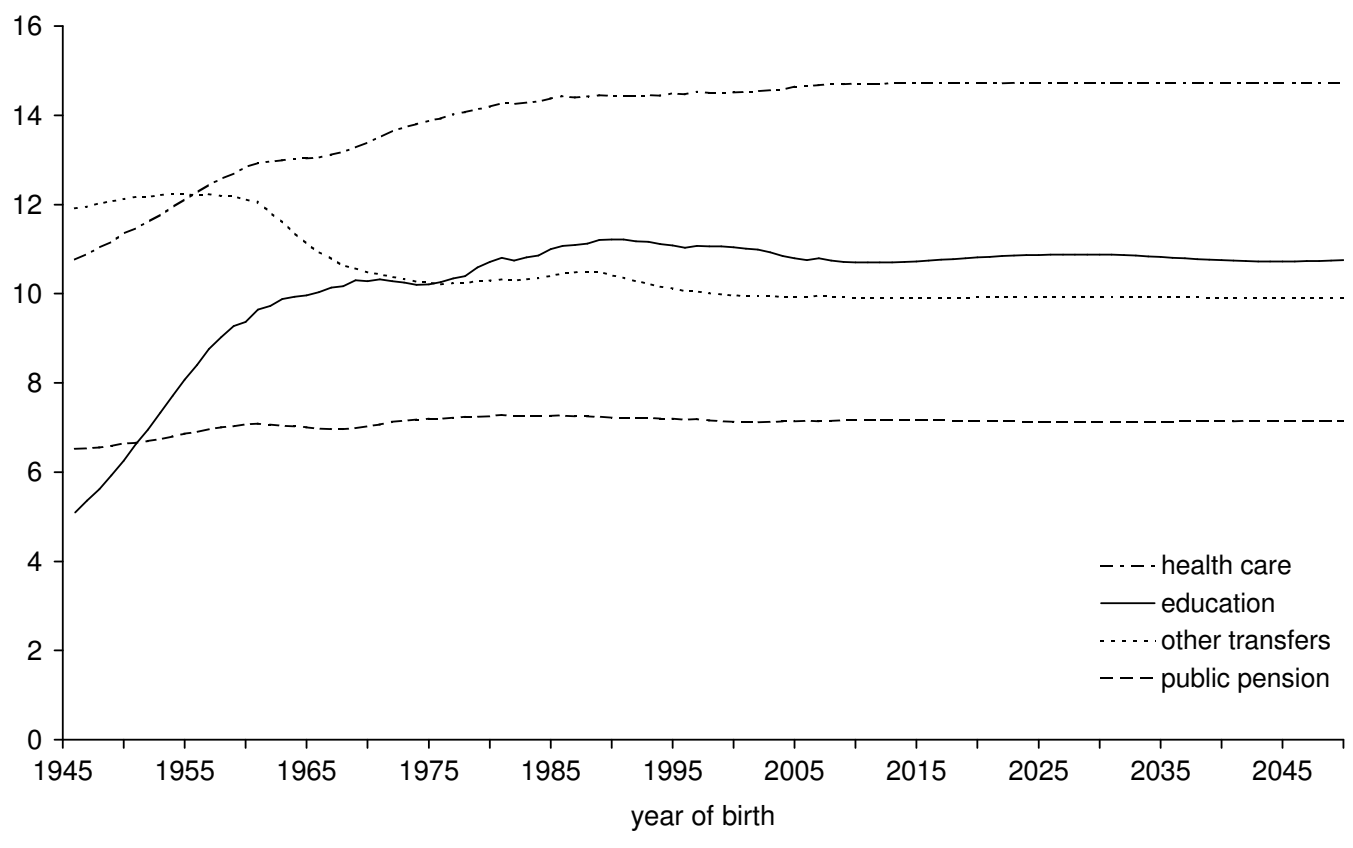

${ }^{26}$ Note that these do not include the private second pillar pensions. 
Figure 5.3 shows the breakdown of lifetime benefits of the expenditure items that can not be directly attributed to individuals and of non-tax revenues. These items are referred to as the 'classical items'. Benefits from general government rise from around $14 \%$ of lifetime income for the oldest cohorts to $16 \%$ for the cohorts born around 1960. This is due to the increase in government expenditure on this item in the first decades after the war. For the cohorts born after 1960 it declines again, mainly as a result of the fact that policy is made sustainable in this scenario by curbing this budget item. Eventually it reaches a level of $10 \frac{1}{2} \%$ of lifetime income. Among the first cohorts there is also a rise, from $3 \frac{1}{2} \%$ to $4 \%$, in the case of benefits from infrastructure. This is the result of high investments in infrastructure in the first decades after the war that led to an increase of the public capital stock. However, lifetime benefits decline again for the cohorts born after around 1975, to a level of eventually $3 \%$, due to the fact that investment levels were curbed in later years. Lifetime benefits from defence decrease with age for all cohorts as a result of the continuous decrease in expenditure since the 1950's.

Figure 5.3 Lifetime benefits of 'classical' expenditure items under scenario 1 (as a percentage of lifetime income)

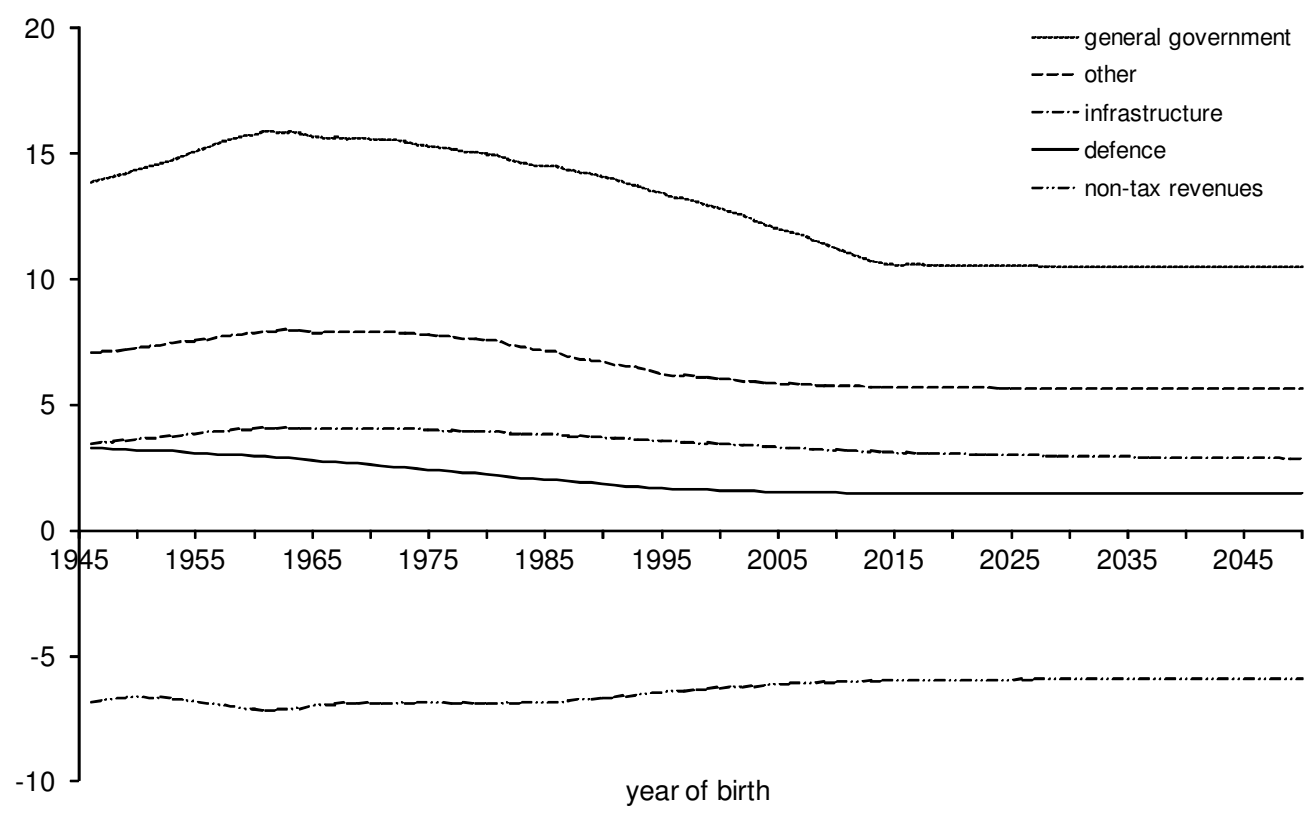

Figure 5.4 decomposes the lifetime tax burdens. Developments therein are far less marked than in the case of benefits from expenditure. The only noticeable changes are those for the first 30 or so cohorts and show slightly declining rates of taxation of households and partially offsetting slightly rising rates of indirect taxation. The pattern of lifetime tax rates across generations is also far flatter than the annual ratios of total taxes to GDP which were presented in Table 3.1. There are two reasons for this. The first is that even the first of the cohorts included in the calculation of lifetime taxation started to pay taxes around 1970 when the annual ratio of total taxes were already higher than in the first decades (see table 3.1). The second reason is that 
lifetime tax rates involve a measurement over a long period of time. Periods with relatively low and relatively high rates of annual taxation are therefore only partly reflected in the lifetime measurement of taxation and may partly even counterbalance each other.

Figure 5.4 Lifetime tax burdens: decomposition of sources of government revenue under scenario 1 (as a percentage of lifetime income)

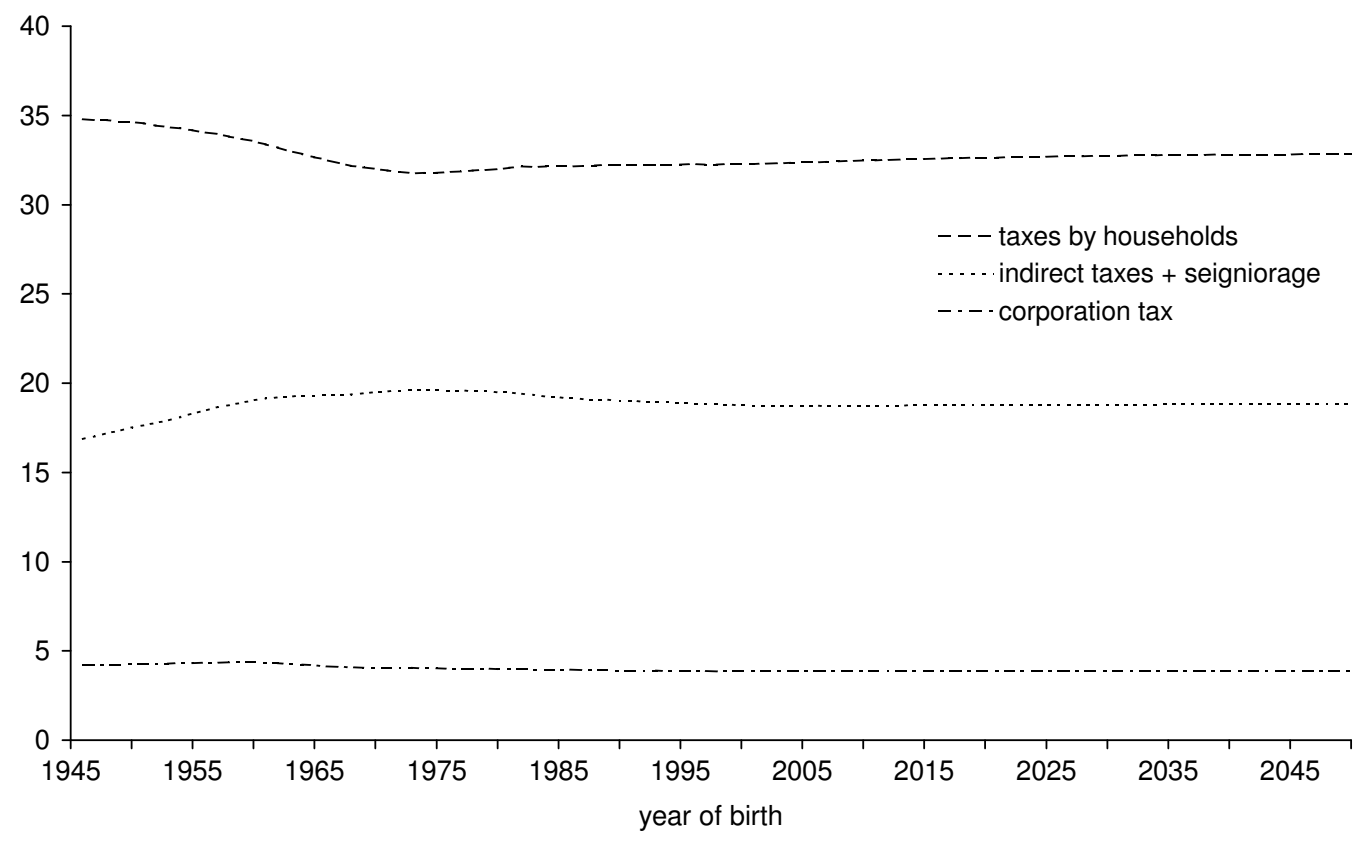




\section{$6 \quad$ Sensitivity analysis}

As already mentioned, in order to check for the robustness of the base case results we made sensitivity analyses. This section presents the results of those analyses. Section 6.1 presents the results of the age profile related sensitivity analyses. Section 6.2 explores the sensitivity for the discount rate.

\subsection{Age profile related sensitivity analysis}

The construction of generational accounts requires an age profile for each item included into the net benefit concept. Age profiles allow to distribute the annual benefits and burdens from the national account items over different age groups. The construction of age profiles is based on either micro-data or knowledge of tax and transfer schemes. For the past however this knowledge is often lacking and for most items we therefore used the same, time invariant, age profiles for past years. Only in the case of education we adjusted the profile in an ad hoc way. By using time invariant age profiles, we implicitly assume that the shape of individual age specific benefits and burdens remained unchanged between 1946 and 2007. This assumption may be questionable for some budgetary items. For two of these items, long term care and taxes on households, we performed a sensitivity analysis, imputing gradually changing age profiles.

And for education we examined the sensitivity for the assumption made in the baseline scenario. These appear to be the items for which the uncertainty about the time invariance of the age profile is the largest.

The current age profile for long term care is extremely skewed toward the very old, i.e. those over 80 . We therefore carry out a sensitivity analysis that measures how the outcomes change if we assume that the profile in the past was less skewed towards the very old. In order to take this into account we adjust the long term care age profile in 1946 in such a way that its shape coincides with that for health care expenses. The latter is much flatter. ${ }^{27}$ From 1946 to 1990 long term care age profiles adjusts gradually to the base case age profile and from 1990 onwards age profiles are the same as in the base case.

The LGAs presented in section 4.1 are based on the assumption that relative tax rates between the various sources remained constant over time. In this baseline exercise, the age profile of taxes in the past only takes account of the varying size of first and second pillar pensions, and of income from government transfers, relative to labour income. This justifies an analysis that explores the effects of assuming diverging relative tax rates in the past. This is done by modifying the relative size of direct taxes on pensions for the years 1946-1990. In 1946, the relative size of tax revenues from pension incomes are assumed to be half of what it is in the baseline. The pensions' relative weight in total taxes then increases linearly up to 1990. From 1990 onwards the age profile is assumed to be equal to that of the base case. Since then

${ }^{27}$ Both age profiles are presented in Van der Horst et al. (2010), pp. 43. 
no major changes in the taxation of pensioners relative to workers have taken place. The uncertainty therefore lies before 1990. By modifying the age profile in the years before 1990 we indirectly also assume a larger weight of all other direct taxes on households, ${ }^{28}$ since the aggregate amount of money raised by the government in direct taxes in each year has to remain the same.

We also performed a sensitivity analysis on education. In this case however we followed the opposite procedure and used modified age profiles in the baseline calculation and an unchanging one in the sensitivity analysis. The baseline took account of the fact that the share of tertiary education in government expenditure on education was lower in 1946 than in 2007 due lower enrolment into university education. The share of education expenses for those older than 17 years was therefore lower in those years. To take this into account we lowered, by $60 \%$, the relative age specific costs for the age group in between 20 and 24 years old in 1946. For the age group between 17 and 19 we interpolated age specific costs. Between 1946 and 1980 we assumed a gradual adjustment towards the current age profile. Our sensitivity analysis will assume that all past age profiles equal the current one.

The exercise is carried out in the scenario in which sustainability is achieved by curbing expenditure in general government. The results (Figure 6.1) show extremely small effects on the overall picture. In the case of long term care the flatter past age profiles leads to slightly higher, around 0.1 percent of lifetime income, net benefits for the cohorts born between 1946 and 1970. These cohorts benefit from the higher benefits at the earlier stages of the life cycle. The effects decline for the younger cohorts due to the gradual adjustment of the age profile towards its current shape and obviously become zero as from the cohort born in 1990. The losers are the cohorts born before 1946. The flatter profile entails lower benefits to them. The main reason for the very small effects is that total expenditure on long term care was very low in the first post war decades, averaging around 0.5 percent of GDP between 1950 and 1970 and not exceeding $2 \%$ percent before 1980 , when the imputed age profile is almost equal to that in the base case.

In the case of lower relative tax rates on pensions, the cohorts born between 1946 and 1970 lose as a result of the fact that a larger share of taxation is now assumed to be borne by the workers in the period before 1990. The older cohorts, who are not included in these calculations as they are born before 1946, gain. Even for the most affected cohort, the 1946 cohort, the effect in only 0.03 percent of lifetime income. The reasons for this is that taxes on pensions amount to only a small part of the total tax revenue and that even the 1946-cohort entered the workforce not before the end of the 1960's when our imputed change of relative taxation is already halfway its adjustment towards the base case.

The analysis with an alternative education profile shows slightly lower benefits for the cohorts born between 1946 and 1975. On average this decline amounts to 0.1 percent of lifetime

\footnotetext{
${ }^{28}$ The aggregate amount of money raised by the government in direct taxes in each year obviously remains unchanged.
} We assumed that all the other taxes increase by the same percentage. 
income. The reason for this is that the flattening of the age profiles, in the years before 1980, entails that on average the benefits now accrue a number of years later in the life cycle and are thus discounted more. The winners of the alternative assumption are the, not included, cohorts born before 1946.

\section{Figure 6.1 Effects of alternative assumptions on age profiles}

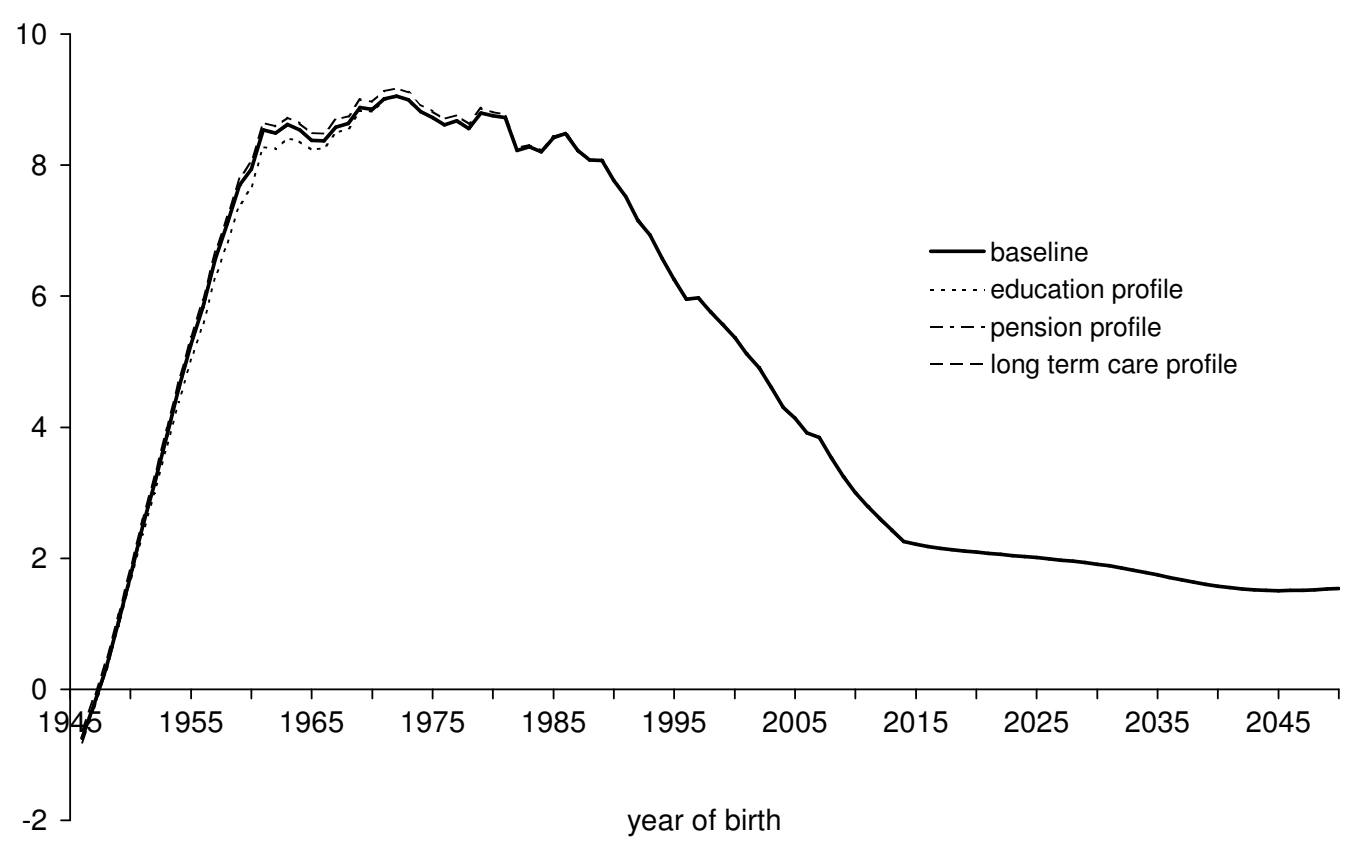

6.2 Sensitivity analysis related to the discount rate

As already discussed, the construction of LGAs requires a discount rate. The choice of the discount rate for future years is based on current returns on assets and current assessments of the equity premium. For past years, this information is either lacking or very time consuming to collect. We therefore imputed the same 3\% real discount rate to past and future. However, the uncertainty about the correct values of these variables for the past justifies a sensitivity analysis and we therefore carried out a sensitivity analysis that explores the effects of a $0.5 \%$-point higher and $0.5 \%$-point lower real discount rate. As real interest rates have turned out to be very constant in the past (Campbell and Viceira, 2002) this degree of variation well covers the uncertainty involved in this parameter.

Figure 6.2 shows the results. The differences with the baseline outcome are now not negligible but the changes of assumption do not alter the basic picture. In the case of a lower discount rate past benefits are valued less, leading to lower net lifetime benefits for current generations. The opposite holds in the case of a higher discount rate.

Figure 6.3 explores the sensitivity of the outcome if we impute an alternative discount rate for both past and future. Here too, the analysis with a higher discount rate turns out to result in higher outcomes and vice versa. 
Figure 6.2 Effects of alternative past discount rates

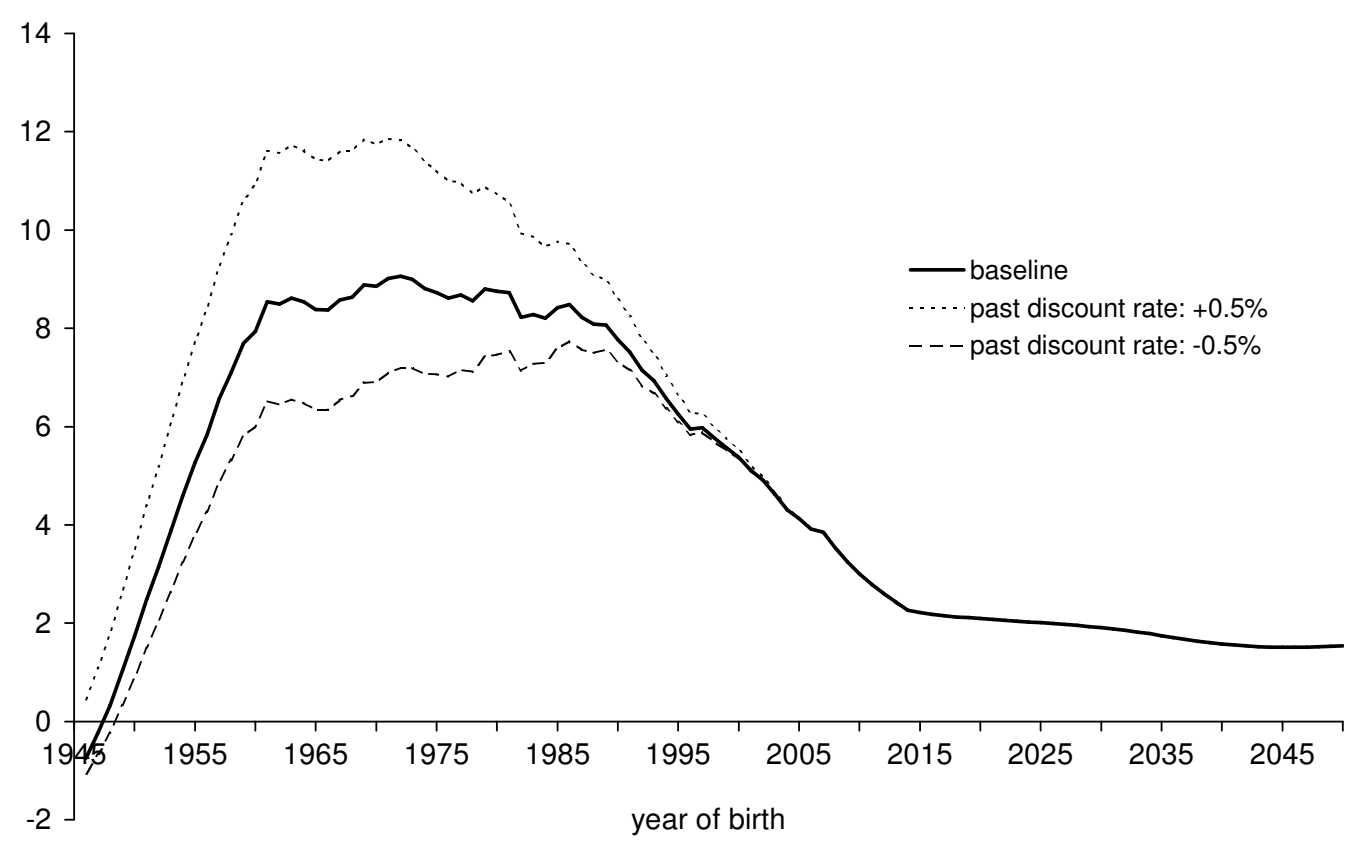

Figure 6.3 Effects of alternative discount rates (past and future)

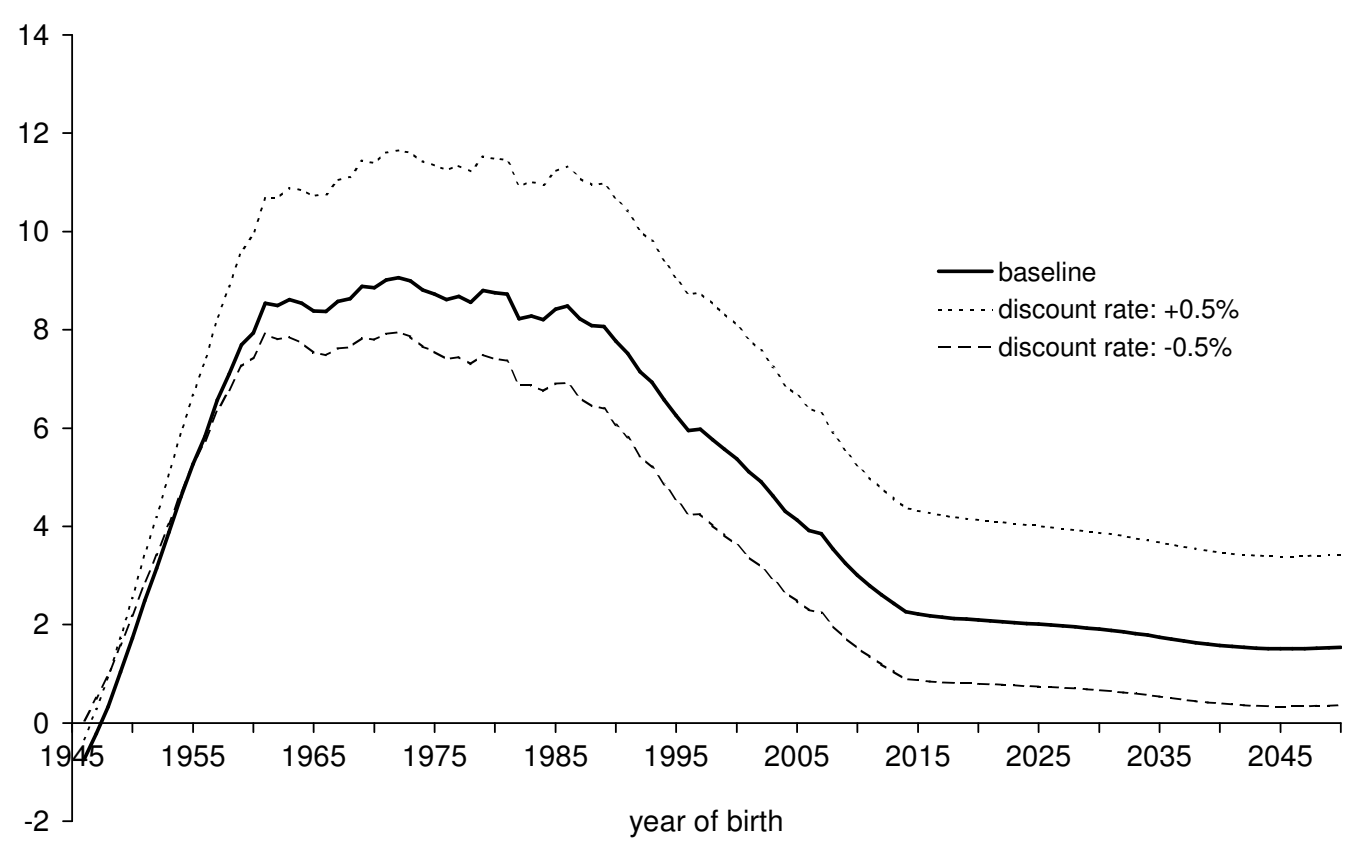




\section{$7 \quad$ Other Lifetime Generational Accounting studies}

The first attempt to produce lifetime generational accounts can be found in Auerbach et al. (1994). In this article the originators of GA dedicate a section to the comparison of currently living and future generations' net tax burdens (taxes paid minus cash transfers received) for the USA. The calculations do not include non-cash benefits such as those from health care, education and other forms of direct government expenditure. Moreover the paper does not provide a detailed account of the methodology. The comparison is done on the basis of the lifetime net tax rate that different generations born in the period 1900-1992 paid. The net tax rate in Auerbach et al. (1994) is defined as the ratio between net taxes discounted at the birth year and the present value (at birth) of the lifetime labour incomes for the generations considered. The lifetime net taxes are calculated using historical data on estimates of actual taxes paid and transfers received in the years 1900 through 1992 along with the projections, for 1993 and subsequent years, of taxes paid and transfers received by age and sex. The projections for 1993 and subsequent years of net taxes are based on the assumption that the fiscal policy in place in 1992 in the US does not change in subsequent years. The lifetime net tax rate that accrues to future generations is expressed in one statistic. It amounts to a staggering 71.1 percent. The results show a clear intergenerational imbalance between current generations and the future cohort in the US. The net tax rates borne by currently alive generations are much lower than that of the future generation. However, there are also substantial differences within the current generations ranging from a lifetime net tax rate of 21.5 percent for the cohort born in 1900 to 33.8 percent for the cohort born in 1980. Auerbach et al. (1994) also shows a breakdown of lifetime net tax rates in lifetime tax rates and lifetime transfer rates. As is clear from the definition of the net tax concept, the paper does not capture possible differences between the cohorts in the non-cash benefits from government.

An updated version of the US Generational Accounts was published by Gokhale et al. (1997). The methodology is the same as in Auerbach et al. (1994), and the results for the current generations are similar. The result for the representative member of future generations, however, is now substantially smaller at 49.2 percent, implying a smaller intergenerational imbalance. In addition, they also present the lifetime net tax rates if government expenditure is curtailed in three ways in order to decrease the intergenerational imbalance between current and future generations. A further update followed in Gokhale et al. (2000). The paper also contained a sensitivity analysis that explores the effect on the net tax rates of alternative assumptions for future expenditure and tax revenues, as well as the effect of several ways of eliminating the intergenerational imbalance.

Outside of the US, an example of LGA calculations can be found in Levy and Doré (1998) for France. One section of this paper is dedicated to the comparison of lifetime net tax payments for the 1950-55 cohort with net tax payments of the young cohorts. The young generation is 
defined as composed of by those younger than 25 in 1995 as well as all future generations. The paper distinguishes only these two sets of cohorts and does not take account of non-cash benefits from government expenditure. The lifetime net tax payments for the 1950-55 generation are calculated by distributing, over individual net payments profiles, national accounts flows ${ }^{29}$ recorded in the 1970-95 period in France. The distribution is based on an age profile derived for 1995 which was adjusted to take into account past changes in the distribution of health care expenditures, indirect taxes and social security taxes. Net tax payments for the young generation are calculated by assuming that cohorts younger than 25 will bear the same net tax burden as all future generations. To compare net payments of the 1950-55 and young generations, the net taxes paid by the 1950-55 generation are discounted to 1950 and then adjusted for productivity growth. The results show an intergenerational imbalance. As for the US, also for France the LGA computation shows that the burden that young generations will bear is much higher than that of old generations.

Another example is Ablett and Tseggai-Bocurezion (2000) for Australia. As the papers mentioned above, this paper excludes non-cash benefits and the other direct government expenditure. It does however provide a detailed description of the methodology applied and a decomposition of the results. The calculations are carried out for the cohorts back to 1900 . The results show a large rise in net tax rates, from $24.3 \%$ of lifetime income to $38 \%$ in the baseline, for the cohorts born between 1900 and 1930. It is not clear to what extent this results from the exclusion of the non-cash benefits and direct government expenditure.

For Canada, Wolfson et al. (1998) developed a model that measures three ways in which the government redistributes, i.e. cross-sectional (at a point in time among households and individuals), intragenerational (over individuals' life cycles) and intergenerational. The latter includes historical taxes and transfers and go back as far as 1890 . However, the measurements include only about one third of expenditure and half of revenues. The calculations do not check for sustainability. As the previous studies they arrive at a favourable treatment of the cohorts born before 1940 relative to the later born cohorts.

For Hungary, Gal and Tarcali (2003) performed an LGA exercise that includes only the contributions to and the benefits from the government pension system. Their calculations show that the cohorts born before 1930 are the net beneficiaries of the pension system and later cohorts, most specifically those born between 1940 and 1960, the net contributors.

\footnotetext{
${ }^{29}$ Income and expenditure of the public administration
} 
For the Netherlands, Van Kempen (1996) carried out LGAs that included the cohorts born between 1960 and 2000. Later cohorts are not included and the imputed policy. As this study, his outcome shows positive lifetime net benefits for the cohorts born in the 1960's . Unlike this study however, cohorts born after 1970 show substantially lower net benefits and these even become negative for the cohorts born as from 1990. This may be due to an earlier adjustment of policy towards sustainability and probably also to differences in the net benefit concept. 


\section{$8 \quad$ Reflection on policy implications}

This paper has concluded that most of the post war generations benefit from government when measured over the full life cycle. The benefits are the largest for the cohorts who are born between 1960 and 1990 and this result turns out to be relatively robust for the various ways in which public finances can be made sustainable in the future without resorting to draconian measures.

An important issue concerns the importance to be given to these full lifetime GAs. As stated in the introduction, comparability of GAs across the current generations requires that past net benefits are included as well. However, one might argue about the weight that has be attached to past net benefits in political decision making regarding intergenerational policies. In the full lifetime GAs, future and past net benefits are obviously weighed equally as, except for the standard practice of discounting, past taxes and benefits are simply added to their future counterparts. Consequently, a preferential or disadvantageous treatment of a generation in the past relative to that of another generation has the same weight as such differences have in the future. This weighting however remains an issue for political decision making, as is any weighting of the effects of government policies, and policy makers may think differently.

A reason for this might be that net benefits in the past, unlike those in the future, where we impute steady state conditions, could be affected by either setbacks or favourable circumstances. For instance, high positive net benefits from government for certain cohorts can be the result of adverse economic circumstances, such as long spells of unemployment, leading to lower tax bases and higher benefits from government transfers. An unequal treatment by government is in this case intentional and follows from government motives to insure and redistribute. In how far the differences in outcome can be attributed to this factor, rather than a favourable treatment by government, is not explored in this paper.

A second reason not to attach an equal weight to the past in political decision making may be that it could be considered inappropriate to fully compensate in the future for a preferential treatment in the past if this would involve large adjustments of policies and bring about substantial and unanticipated negative shocks in the welfare of the older generations. Note that this would also involve a change in policy rules, and that these generations were at the time not even aware of any preferential treatment due to the complicatedness and lack of transparency of such calculations.

Table 8.1 provides information on this issue. It shows the effect on remaining lifetime welfare (defined as the present value of future private consumption and net benefits from government) per 1 percentage-point change in lifetime net benefit. Per percentage-point it would, for instance, entail a 5\% change in remaining lifetime welfare for the 1946-cohort and a $2.9 \%$ change for the 1958 cohort. 
Table 8.1 Effect of a $1 \%$ change in lifetime net benefit on remaining lifetime welfare (in percentages)

Year of birth

1946

1958

1970

1982

1995

2008 


\section{References}

Ablett, J, and Z. Tseggai-Bocurezion, 2000, Lifetime Net Average Tax Rates in Australia Since Federation- A Generational Accounting Study, The Economic Record, vol. 76, 139-151.

Alessie, R. and J. de Ree, 2009, Explaining the hump in life cycle consumption profiles, De Economist, 157, pp. 107-120.

Auerbach, A., J. Gokhale, and L. Kotlilkoff, 1991, Generational Accounts- A Meaningful Alternative to Deficit Accounting, NBER Working Paper 3589.

Auerbach, A., J. Gokhale, and L. Kotlilkoff, 1994, Generational Accounting- A Meaningful Way to Evaluate Fiscal Policy, Journal of Economic Perspectives, 8, 73-94.

Auerbach, A., J. Gokhale, and L. Kotlilkoff, 1999, Generational Accounting around the World, The University of Chicago Press.

Besseling, P., A.L. Bovenberg, G. Romijn en W. Vermeulen, 2008, De Nederlandse woningmarkt en overheidsbeleid: een lange termijn perspectief, in Koninklijke Vereniging voor de Staatshuishoudkunde, Agenda voor de Woningmarkt.

Bos, F., 2006, De Nederlands collectieve uitgaven in historisch perspectief, CPB Document 109, The Hague.

Buiter, W., 1995, Do generational accounts reveal the effect of the budget on savings and intergenerational redistribution?, NBER working paper 5087.

Campbell, J.Y, and L.M. Viceira, 2002, Strategic Asset Allocation, Portfolio Choice for Long Term Investors, Oxford University Press.

CPB, 1999, Woningbouw: tussen markt en overheid, Special CPB Publication 17.

Draper, D.A.G. and A. Armstrong, 2007, Gamma, a simulation model for ageing, pensions and public finances, CPB Document 147, The Hague.

Fehr, H. and L.J. Kotlikoff, 1999, Generational Accounting in General Equilibrium, Chapter 3 in Generational Accounting around the World, edited by A. Auerbach, L. Kotlikoff and W. Leibfritz, The University of Chicago Press. 
Gal, R.J. and G. Tarcali, 2003, Pension Reform and Intergenerational Redistribution in Hungary, paper presented at the PIE International Workshop on 'Pension Reform in Transition Economies', IER Hitotsubashi University.

Gokhale, J, B. Page, and J. Sturrock, 1997, Generational Accounts for the United States: An Update, Economic Review (Federal Reserve Bank of Cleveland), 4th Quarter 1997, 2-23.

Gokhale, J, B. Page, J. Potter, and J. Sturrock, 2000, Generational Accounts for the United States: An Update, American Economic Review, 90, 293-296.

Haveman, R., 1994, Should generational accounts replace public budgets and deficits?, Journal of Economic Perspectives, 8(1):95-111.

Euwals, R. en K. Folmer, 2009, Arbeidsaanbod en gewerkte uren tot 2050, CPB Memorandum 225.

Ewijk, C. van, N. Draper, H. ter Rele, and E. Westerhout, 2006, Ageing and the Sustainability of Dutch Public Finances, Special CPB Publication 42, The Hague

European Commission, 2009, Sustainability Report-2009, European Economy 9/2009.

Kotlikoff, Laurence J., 1992, Generational Accounting, Knowing Who pays, and When, for What we Spend, The Free Press.

Kempen, E.J. van, 1996, Betaalt de baby de boom?, Economisch Statische Berichten, pp. 724-728.

Levy, J. and O. Doré, 1999, Generational Accounts for France, Chapter 11 in Generational Accounting around the World, edited by A. Auerbach, L. Kotlikoff and W. Leibfritz, The University of Chicago Press.

RIVM, 2007, Kosten van Ziekten, RIVM, the Netherlands.

Ter Rele, H., 1998, Generational accounts for the Netherlands, De Economist, 146, 555-584.

Van der Horst, A, L. Bettendorf, D. Draper, C. van Ewijk, R. de Mooij en H. ter Rele, 2010, Vergrijzing Verdeeld, Special CPB Publication 86, The Hague. 
Van Sonsbeek, J.M., en R. Alblas, 2010, Lange termijn raming

arbeidsongeschiktheidsregelingen, January 2010, Ministry of Social Affairs and Employment.

Wolfson, M., G. Rowe, X. Lin, S. Gribble, 1998, Historical Generational Accounting with

Heterogeneous Populations, Chapter 8 in Government Finances and Generational Equity,

Statistics Canada. 
Publisher:

CPB Netherlands Bureau for Economic Policy Analysis

P.O. Box $80510 \mid 2508$ GM The Hague

$\mathrm{T}(070) 3383380$

March 2011 | ISBN 978-90-5833-498-5 